This PDF is a simplified version of the original article published in Internet Archaeology. Enlarged images which support this publication can be found in the original version online and all links also go to the online version.

\title{
Iron Age Settlements and Roman Roads: archaeological fieldwork along the Angelinos trunk water main in north Oxfordshire
}

Owain Scholma-Mason, Michael Tierney, Hayley Goacher and Matt Edgeworth with contributions by Jane Timby, Veronica Anicetti, Mauro Rizzetto, Sue McGalliard, Richard Macphail, Julie Lochrie, David Henderson, Angela Walker and Holly B. Duncan. Illustrations by Beata Wieczorek-Oleksy

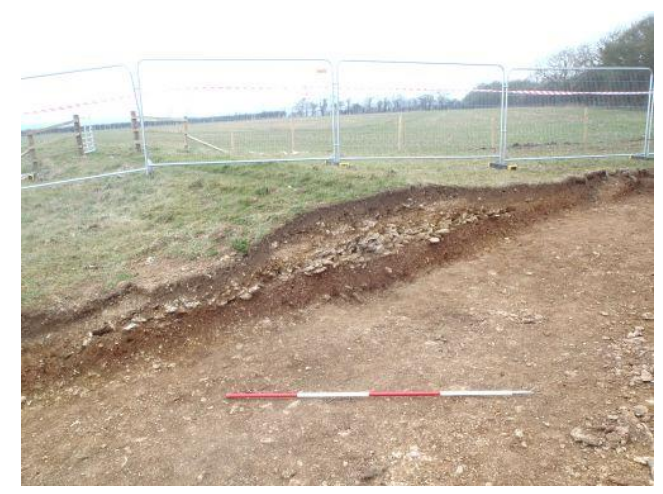

Akeman Street Roman road under excavation

Excavations along an $18.5 \mathrm{~km}$ stretch of the Angelinos trunk water main in north Oxfordshire between Tackley and Milton uncovered a panoply of prehistoric to postmedieval remains. Residual sherds of Beaker pottery suggest Chalcolithic/early Bronze Age activity within the vicinity of the development, but most of the excavated features were middle Iron Age in date, comprising linear boundaries and probable enclosures. At least three areas of domestic occupation were recorded, ranging from a single structure to multiple pits associated with various linear features. A double burial, comprising an adult male and a child, dating to the middle Iron Age was also recorded. Roman remains were largely limited to a section dug through Akeman Street, which formed a key arterial route during the Roman period. Other Roman evidence includes a possible midden or manure spread, suggestive of nearby agricultural activity. Medieval and post-medieval features ranged from plough marks to probable quarry pits. 


\section{Introduction}

This report presents the results of a programme of archaeological mitigation and observation works undertaken by Headland Archaeology UK Ltd in 2016 in advance of the construction of the new Angelinos trunk water main. The development corridor extended from Angelinos Pumping Station, about $2 \mathrm{~km}$ south-west of Tackley, to the Milton Pumping Station, roughly 300m south-east of Milton (Figure 1) in Oxfordshire (UK). It was aligned on a south-north axis, $18.5 \mathrm{~km}$ long and $0.03 \mathrm{~km}$ wide, with eleven targeted excavation areas covering 3.91 ha. Significant concentrations of archaeological remains were encountered in Area 2, Area 3, Area 7 and Area 10. No archaeological remains were recorded in Areas 6 and 8.
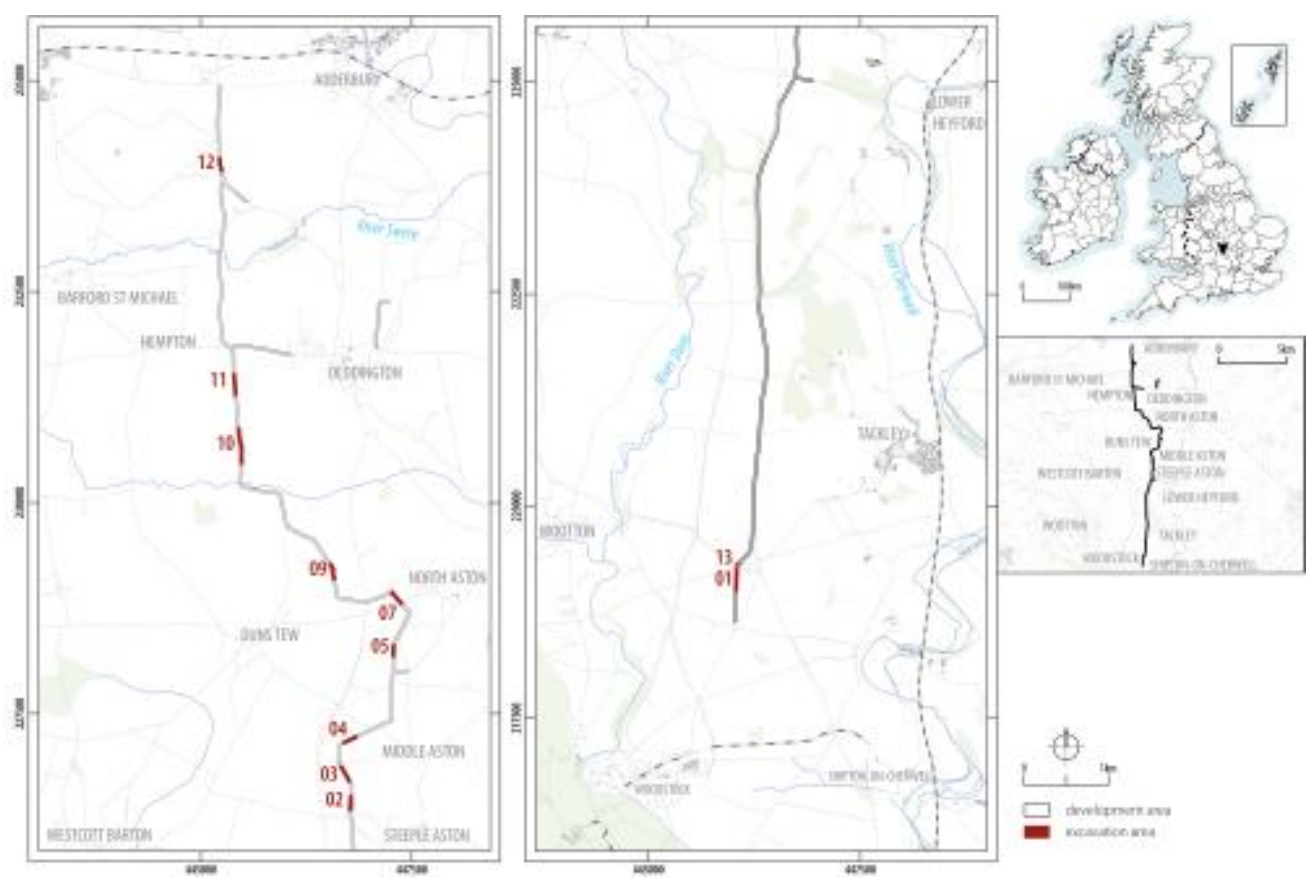

Figure 1: Site location

The course of the pipeline is bounded to the east by the Cherwell River valley and to the west by the Dorn River valley (Figure 1). Elevation varies from $81 \mathrm{~m}$ above Ordnance Datum (aOD) to the highest at $145 \mathrm{~m}$ aOD. In geomorphological terms, the landscape to the south is predominantly low-lying level plains giving way to scarp slopes

approximately halfway along the pipeline. The central to northern extent of the pipeline is dominated by steeply incised stream and river valleys cutting through the scarp and flowing into the Cherwell, Dorn and Swere Rivers (Figure 1). The predominant bedrock geology of the southern part of the pipeline is middle Jurassic limestone of the Great Oolite Formation, before transitioning to middle Jurassic marine calcareous mudstone of the Lias Formation in the northern part.

\section{Archaeological Background}

A significant number of archaeological sites and find spots are known within the immediate area of the development, with many more along the Upper Thames Valley terraces further to the south (Figure 2). The general archaeological background of the 
region has been summarised in a number of individual site reports (e.g. Miles et al. 2007; Hey et al. 2011; Lambrick and Allen 2004) and regional syntheses (e.g. Morigi et al. 2011; Lambrick and Robinson 2009; Booth et al. 2007; Smith et al. 2016; Gill and Hind 2014). Therefore, only a summary account of the archaeology around the area of the development is presented here. The wider context and interrelationships of the excavated sites is revisited in the final part of this report.

Interactive figure - online only

Figure 2: The site in its wider context [Download large image]

This discussion draws on several sources, including the desk-based assessment undertaken prior to the evaluation (Lang Hall 2014) alongside a review of cropmark and HER data. A number of the recorded sites within the immediate region derive from antiquarian investigations, or are stray finds for which there is little extant information. Close to the development, several cropmarks visible on aerial photographs are suggestive of further sites, including a probable banjo enclosure and a series of linear boundaries or enclosures (Figure 2) (see also Featherstone and Bewley 2000 for an overview). The dating and interpretation of these is reliant on their morphology, limiting discussion of these and their relationship to excavated features within the corridor.

\subsection{Mesolithic to Later Bronze Age}

Earlier prehistoric activity within the development corridor was identified primarily in the form of Mesolithic or Neolithic flint scatters (HER 901, HER 3425). Residual Neolithic tools were recorded at Wood Farm near Tackley (HER 4001), c. $2 \mathrm{~km}$ north-east of Area 13, and at Heyford Road, 1.4km to the south-east of Area 2 (Cook and Hayden 2000) (Figure 2). A probable Neolithic long barrow (HER 4682) is recorded 1.6km to the southwest of Area 2. Excavations at Yarnton, c. 8.2km to the south of the development, revealed a series of prehistoric features, including a substantial early Neolithic house alongside traces of midden activity, pit digging, and funerary activity dating to the late Neolithic and the early to middle Bronze Age (Hey et al. 2016). Other Bronze Age sites in the area include a series of probable barrows near Bicester (HER 5633; Wessex Archaeology 2006), c. $11 \mathrm{~km}$ east of Area 1 and a probable barrow cemetery near Enstone, c. $7 \mathrm{~km}$ to the west of Area 2 (HER 16876).

\subsection{Iron Age}

Iron Age activity is widely recorded within the surrounding area of the development and includes several excavated sites as well as probable Iron Age enclosures identified through aerial photography (Lang Hall 2014). A series of cropmarks, probable ditches, and enclosures were recorded $0.6 \mathrm{~km}$ to the south-west of Area 7, alongside the possible remains of a banjo enclosure (Figure 2).

Excavations at Heyford Road, 1.2km to the south-east of Area 2, revealed the remains of several pits and a series of ditches defining a probable enclosure or boundary dating to between the 4th and early 2nd century BC (Cook and Hayden 2000). From the fill of the pits disarticulated human remains were recovered (Cook and Hayden 2000). Further Iron Age settlement remains were recorded $400 \mathrm{~m}$ to the south-east of these, although the precise nature of the site is unclear (HER 4211). A middle Iron Age 'clothes-line' 
enclosure system was excavated at Duns Tew, $0.24 \mathrm{~km}$ to the south of Area 10 (Figure 2). The system was primarily defined by an east to west linear land boundary that ran for c. $210 \mathrm{~m}$, linking two substantial domestic enclosures (Hewitt 2016). The easternmost enclosure comprised a four-sided polygon roughly $53 \mathrm{~m}$ by $45 \mathrm{~m}$, with a roundhouse located in the centre.

Excavation in advance of the Thames Water mains reinforcement between Kirtlington and Ardley (APST Pipeline) reservoir in 2004 to 2005 revealed the remains of three middle to late Iron Age settlements to the north-west of Middleton Stoney (Hart et al. 2010) (Figure 2). Two of the settlements (Enclosures 1 and 2, Area 5) were enclosed, while the third (Area 6) appeared to be unenclosed. To the east of the enclosures were the remains of Aves Ditch, running roughly north-east to south-west. A small section was dug through the boundary, showing that Aves Ditch was probably contemporary with the later phases of Iron Age settlement (Hart et al. 2010, 137). Aves Ditch forms a key landscape feature of the Iron Age, running for about $4.2 \mathrm{~km}$ in a north-easterly line from Kirtlington, forming part of the modern parish boundary between Upper Heyford and Middleton Stoney. It has been suggested that it represents a territorial boundary at the western end of Catuvellaunian influence (Sauer 2005; Lambrick and Robinson 2009, 368-70).

Other settlements in the wider area include a mid- to late Iron Age enclosed farmstead at Bicester Fields Farm, c. 12km to the east of Area 2 (Cromarty et al. 1999) and unenclosed middle Iron Age farmsteads at Slade Farm (Ellis C. 2000) and at Foxley Fields Farm (Grundon 1998), c. 11 km to the north of Bicester Fields Farm (Figure 2).

\subsection{Roman}

Roman activity is well attested within the region, with recorded sites ranging from probable Roman buildings and settlements to stray finds of Roman coins or pottery. Concentrations of Roman remains have been recorded around Steeple Aston, Bloxham and Bicester (Figure 2). A key feature of the landscape during the Roman period was Akeman Street, crossing the route of the current pipeline. This road linked Cirencester (Corinium Dobunnorum) with St Albans (Verulamium), and there was speculation regarding whether it could have been preceded by a pre-Roman route (Johnson 1979; Copeland 2009; see also Salway 1999, 9-10, and discussion below). In 2019, Oxford Archaeology excavated a section of Akeman Street at Graven Hill near Bicester (Allen et al. 2020) (Figure 2), providing important information about its construction. Other trackways of Roman date are known in the region (cf. Booth 2011) including the remains of a probable trackway at Heyford Road, which may have succeeded an earlier Iron Age one (Cook and Hayden 2000, 209).

Recorded Roman settlements within the development area range from isolated buildings to larger urban centres to small farmsteads and probable high-status villas. Among the latter are the remains of a probable Roman villa, $c .1 .5 \mathrm{~km}$ to the south of Area 2 , investigated in 1658 by the antiquarian Anthony Wood (HER 1749) (Clark 1891, 264; Plot 1705, 335; see also Wing 1877). Excavations at Hopcrofts Holt Hotel, 0.4km to the north of the probable villa, uncovered the remains of a low-status farmstead dating to $c$. AD 50-150 (Lawrence and Hardy 1996). Human remains were recorded in 1870 immediately to the east of Hopcrofts Holt Inn, and north of the road from the Inn to Lower Heyford, although the date of these remains is unclear (Manning 1898, 10). Spreads of 
material at Blackingrove Farm, $1.1 \mathrm{~km}$ to the south-west of Area 12, are suggestive of domestic activity within the immediate vicinity (Salzman 1939, 331).

Further possible villa sites are recorded at Manor Farm near Great Tew (Fearon 1971), c. 1.8km east of Area 10, and Beaconsfield Farm (HER 2336), c. 6km to the west of Area 4 (Figure 2); the latter comprised the remains of an elaborate courtyard villa, discovered in 1810 and partly excavated in 1827, 1950, 1951 and 1965. At Middleton Stoney, c. $7 \mathrm{~km}$ to the south-east of Area 2, excavations in 1970 revealed the remains of a rectangular Roman building, associated with further structures and wall sections (Rahtz and Rowley 1984). The remains likely define a small settlement or villa complex, originating in the late 1st/early 2nd century AD (Rahtz and Rowley 1984).

Larger urban centres are also recorded in the area, notably at Alchester near Bicester, a 'small town' that originated as a conquest-period fortress and formed a key part of the Roman landscape (Sauer 2006; Simmonds and Lawrence 2018, 5) (Figure 2). Further settlement remains are recorded around the Bicester area, including at Bicester Park, where a series of mid-late Roman rectilinear enclosures were excavated (Westgarth and Carlyle 2008). Smaller nucleated settlements in the region include that at Sansoms Platt, Tackley, just to the south of Akeman Street (Figure 2). The site, largely known from cropmark data and limited excavation, comprises a metalled road flanked by several buildings (Winton 2001).

\subsection{Saxon and medieval}

Saxon and medieval settlements and funerary sites are widely recorded across the region. Among the latter are the Anglo-Saxon inhumation cemeteries at Somerton (HER 1705), 2.3km to the east of Area 5, and at Upper and Lower Heyford (HER 1764, 17003) to the east of the pipeline (Figure 2). Evidence of Saxon settlement is more constrained, although several probable sites have been recorded, including at land north of Gossway Fields, Kirtlington, $3.9 \mathrm{~km}$ east of Area 1. Excavations revealed the remains of two AngloSaxon sunken-featured buildings (SFB) adjacent to the Roman road running from Akeman Street to north Oxford (Gilbert 2005).

Several deserted medieval villages are recorded across the wider area, largely identified based on extant earthworks and aerial photography. These include the villages at Dornford, Ilbury and Ludwell, located to the west of the pipeline corridor (Figure 2). Medieval settlement was recorded to the west of Duns Tew village (HER 17171), 1.9km to the west of Area 5, and recently at Graven Hill near Bicester (Allen et al. 2020). These sites are frequently associated with areas of ridge and furrow, which is widely recorded across the region, including across the development corridor (Lang Hall 2014). At the time of excavation, the land targeted for development was for the most part in agricultural use, with the present-day field system being generally representative of postmedieval enclosure. 
Table 1: Summary of excavated areas

\begin{tabular}{|c|c|c|c|c|c|c|}
\hline Area & $\begin{array}{c}\text { Pipeline } \\
\text { Section Length } \\
\text { m }\end{array}$ & $\begin{array}{l}\text { Approx } \\
\text { area (ha) }\end{array}$ & No. Trenches & Easting & Northing & Fig \\
\hline EX01 & 298.7 & 0.51 & $\begin{array}{l}1: 149 \mathrm{~m} \times 15 \mathrm{~m} \\
2: 66 \mathrm{~m} \times 6 \mathrm{~m}\end{array}$ & 446037 & 219152 & 4,5 \\
\hline EX02 & 175.47 & 0.30 & $1: 176 \mathrm{~m} \times 10 \mathrm{~m}$ & 446780 & 226447 & 7 \\
\hline EX03 & 215.76 & 0.37 & $\begin{array}{c}\text { 1: } 126 \mathrm{~m} \times 4 \mathrm{~m}, \text { northern edge } \\
\text { extended to } 11 \mathrm{~m} \text { wide }\end{array}$ & 446711 & 226794 & 11 \\
\hline EX04 & 178.03 & 0.30 & $1: 178 \mathrm{~m} \times 12 \mathrm{~m}$ & 446766 & 227192 & 12 \\
\hline EX05 & 143.81 & 0.24 & $1: 98 \mathrm{~m} \times 6.5 \mathrm{~m}$ & 447287 & 228260 & 13 \\
\hline EX07 & 188.52 & 0.32 & $\begin{array}{c}1: 97 m \times 7 m, \text { eastern extent } \\
\text { extended to } 15 \mathrm{~m}\end{array}$ & 447322 & 228862 & 14 \\
\hline EX09 & 210.42 & 0.36 & $1: 176 \mathrm{~m} \times 7 \mathrm{~m}$ & 446558 & 229194 & 16 \\
\hline EX10 & 434.07 & 0.74 & $1: 425 \mathrm{~m} \times 7 \mathrm{~m}$ & 445466 & 230690 & 17 \\
\hline EX11 & 256.6 & 0.44 & $1: 145 \mathrm{~m} \times 7 \mathrm{~m}$ & 445397 & 231426 & 18 \\
\hline EX12 & 171.87 & 0.29 & $\begin{array}{l}1: 72 \mathrm{~m} \times 8 \mathrm{~m} \\
2: 73 \mathrm{~m} \times 7 \mathrm{~m}\end{array}$ & 445226 & 234007 & 17 \\
\hline EX13 & 23.43 & 0.04 & 1: $172 \mathrm{~m} \times 8 \mathrm{~m}$ & 446030 & 219285 & 5 \\
\hline
\end{tabular}

Of the $18.5 \mathrm{~km}$ of the development corridor, $2.82 \mathrm{~km}$ was subjected to a scheme of archaeological mitigation, comprising eleven targeted excavation areas, covering a total area of 3.91 ha (Table 1, Figure 1). A further 13 areas of the development were subject to archaeological monitoring during topsoil stripping, though no archaeology was encountered (Headland Archaeology 2016). All of these areas were defined using the results of a desk-based study undertaken prior to the development (Lang Hall 2014) and geophysical survey by Stratascan $(\underline{2015})$. The results of the latter are further detailed in the discussion of the archaeology of each excavated area.

Topsoil and subsoil were removed by mechanical excavator under archaeological supervision across the whole of the pipeline (Headland Archaeology 2016 ). A 17m wide area of topsoil was stripped incorporating the full width of the development's designated work area, and a $7 \mathrm{~m}$ subsoil strip targeting the line of the pipeline which was deemed as having the highest level of impact. Where necessary, owing to the presence of archaeological remains, subsoil was removed within the full $17 \mathrm{~m}$ work corridor. As per the Written Scheme of Investigation (Headland Archaeology 2016), where linear features were encountered a suitable sample was excavated to characterise the feature, 
typically comprising $1 \mathrm{~m}$ wide sections. Pits and post-holes were fully excavated, with post-holes being half-sectioned initially (Headland Archaeology 2016).

Area 13 at the southern end of the scheme was focused on the former route of Akeman Street, a Roman road extending from Cirencester to St Albans. As part of the excavations of Akeman Street, three thin-section samples were taken - two from soil buried beneath the Roman road and one from the roadside silts (see Macphail, this article).

\section{Project Aims}

In accordance with the project methodology the broad aim of the archaeological works was to characterise the distribution, date, and condition of archaeological remains along the length of the pipeline (Headland Archaeology 2016). Following the excavation and initial assessment, a series of research aims were defined (Spencer et al. 2017), which were tied into wider research aims set out in the regional research framework (Gill and Hind 2014). The following are the revised research aims and objectives relevant to the current publication:

- Middle to late Iron Age (400 BC-AD 43):

- Factors leading to shifts in settlement location in the late Iron Age

- The size of communities in the Iron Age, their social and economic relationships, and the degree of economic specialisation.

- Roman (AD 43-AD 410):

- The evidence for major change in settlement occupation across the region

- The nature of settlement and land division during the Roman period, including consideration of the wider Roman landscape and role of Akeman Street.

\section{Structure of this Report}

The main part of this report is divided into three sections. The first part presents the results of the excavations across the Angelinos Pipeline. Given the size of the development corridor, no attempt is made at presenting all the detail recovered, but further descriptions of the excavations, including detailed overviews of all the recorded features, can be found within the post-excavation assessment report held by the Archaeology Data Service (ADS) (Spencer et al. 2017).

After an initial summary by phase, the results of the excavations are presented by excavation area, progressing from the southern to northern terminus of the pipeline. The second part presents a summary of the artefactual and environmental data recovered from across the pipeline. Detailed accounts and quantifications can be found in the postexcavation assessment report (Spencer et al. 2017). The final element of the report presents a detailed review of the results of the excavations and how they relate to the wider archaeological landscape. 


\section{Location of the Archives}

All the original records for each excavation area, including the finds and material generated during post-excavation analysis, have been deposited with the Oxfordshire Museum Services (Archive no. OXCMS: 2016.159), to facilitate access for future research and interpretation. A copy of the post-excavation assessment report is held online at OASIS (headland4-242490).

Table 2: Summary of main phases by area

\begin{tabular}{|c|c|c|c|}
\hline Area & Periods & Key features & Figure \\
\hline$\underline{1 / 13}$ & Roman & $\begin{array}{c}\text { Roman road - Akeman Street } \\
\text { ?Trackway } \\
\text { Ditches }\end{array}$ & 4,5 \\
\hline \multirow[t]{2}{*}{$\underline{2}$} & Middle Iron Age & $\begin{array}{c}\text { Ditches - field boundaries, ?enclosure } \\
\text { Pits } \\
\text { Burial }\end{array}$ & \multirow[t]{2}{*}{7} \\
\hline & ?Post-medieval & Quarry pits & \\
\hline$\underline{3}$ & Middle Iron Age & $\begin{array}{l}\text { Boundary ditches } \\
\text { Structure } 1\end{array}$ & 10 \\
\hline$\underline{4}$ & Middle Iron Age & Ditch - part of possible enclosure & 11 \\
\hline$\underline{5}$ & Undated & $\begin{array}{l}\text { Ditch } \\
\text { Pits }\end{array}$ & 12 \\
\hline \multirow[t]{2}{*}{$\underline{7}$} & Middle Iron Age & $\begin{array}{l}\text { Curvilinear ditches } \\
\text { Pits }\end{array}$ & \multirow[t]{2}{*}{13} \\
\hline & Roman & Colluvial layer & \\
\hline$\underline{9}$ & ?Middle Iron Age & Boundary ditch & 14 \\
\hline \multirow{3}{*}{$\underline{10}$} & Chalcolithic/Early Bronze Age & Residual Beaker pottery & \multirow{3}{*}{15} \\
\hline & Roman & $\begin{array}{c}\text { Colluvial layer } \\
\text { Ditches } \\
\text { Post-hole (structured deposit?) }\end{array}$ & \\
\hline & Medieval/post-medieval & $\begin{array}{l}\text { Quarry pits } \\
\text { Furrows }\end{array}$ & \\
\hline$\underline{11}$ & Medieval/post-medieval & Furrows & 16 \\
\hline$\underline{12}$ & Chalcolithic/Early Bronze Age & $\begin{array}{l}\text { Residual Beaker pottery } \\
\text { Enclosure ditches }\end{array}$ & 17 \\
\hline
\end{tabular}




\section{Results of the Excavation}

The archaeology within the pipeline primarily spans the Iron Age and Roman periods, with limited evidence for activity before or after this (Table 2).

\subsection{Radiocarbon dating}

Seven samples were submitted for radiocarbon dating and most returned dates spanning the middle Iron Age. These dates are summarised in Table 3. Calibrated date ranges were calculated using the calibration curve of Reimer et al. (2020) and OxCal v 4.4 (Bronk Ramsay 2009) (Figure 3).

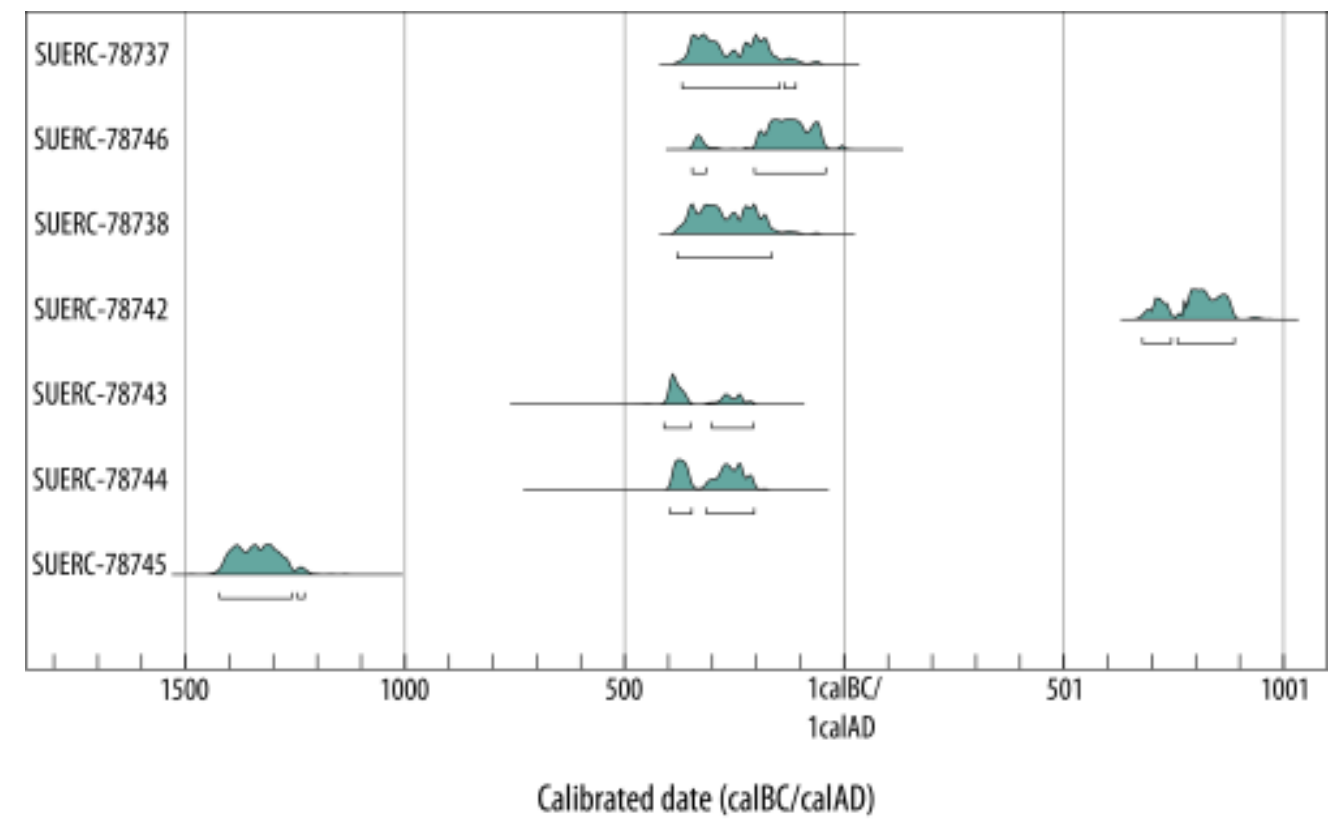

Figure 3: Calibrated radiocarbon dates

\subsection{Phasing summary}

The excavated features from the Angelinos pipeline can be assigned to four broad chronological periods:

Chalcolithic/early Bronze Age: Two sherds of Beaker pottery dating to the Chalcolithic/early Bronze Age, were recovered in Area 12 and Area 10. Given the limited size and condition of the assemblage, combined with the absence of additional datable material, these sherds are probably residual. 
Table 3: Summary of radiocarbon dates

\begin{tabular}{|c|c|c|c|c|c|c|}
\hline Are & ontext & Feature & Material dated & $\begin{array}{l}\text { Sample } \\
\text { ID }\end{array}$ & $\begin{array}{l}\text { Uncal } \\
\text { Date } \\
\text { (BP) }\end{array}$ & $\begin{array}{l}\text { Cal Date } \\
(95.4 \%)\end{array}$ \\
\hline 2 & 2044 & $\begin{array}{c}\text { Deliberate } \\
\text { deposit in pit } \\
\text { [2045] }\end{array}$ & $\begin{array}{l}\text { Charred cereal } \\
\text { grain, Triticum sp. }\end{array}$ & $\begin{array}{l}\text { SUERC- } \\
78737\end{array}$ & $\begin{array}{l}2181 \\
\pm 35\end{array}$ & $\begin{array}{c}370-111 \\
\text { cal BC }\end{array}$ \\
\hline 2 & 2084 & $\begin{array}{l}\text { Human remains } \\
\text { from pit [2084] }\end{array}$ & Bone, human & $\begin{array}{l}\text { SUERC- } \\
78746\end{array}$ & $\begin{array}{l}2116 \\
\pm 35\end{array}$ & $\begin{array}{c}346-43 \text { cal } \\
\text { BC }\end{array}$ \\
\hline 2 & 2086 & $\begin{array}{c}\text { Primary deposit } \\
\text { of pit/burial pit } \\
\text { [2084] }\end{array}$ & $\begin{array}{l}\text { Charred cereal } \\
\text { grain, Triticum sp. }\end{array}$ & $\begin{array}{l}\text { SUERC- } \\
78738\end{array}$ & $\begin{array}{c}2197 \\
\pm 35\end{array}$ & $\begin{array}{c}381-166 \\
\text { cal BC }\end{array}$ \\
\hline 4 & 4005 & $\begin{array}{l}\text { Primary deposit } \\
\text { of ditch [4006] }\end{array}$ & $\begin{array}{c}\text { Charred cereal } \\
\text { grain, Triticum sp. }\end{array}$ & $\begin{array}{l}\text { SUERC- } \\
78742\end{array}$ & $\begin{array}{l}1223 \\
\pm 35\end{array}$ & $\begin{array}{l}680-889 \\
\text { cal AD }\end{array}$ \\
\hline 7 & 7015 & $\begin{array}{c}\text { Secondary } \\
\text { deposit of pit } \\
{[7020]}\end{array}$ & $\begin{array}{l}\text { Charred cereal } \\
\text { grain, Triticum sp. }\end{array}$ & $\begin{array}{l}\text { SUERC- } \\
78743\end{array}$ & $\begin{array}{c}2300 \\
\pm 35\end{array}$ & $\begin{array}{l}411-208 \\
\text { cal BC }\end{array}$ \\
\hline 7 & 7066 & $\begin{array}{c}\text { Secondary } \\
\text { deposit of pit } \\
\text { [7068] }\end{array}$ & $\begin{array}{c}\text { Charred cereal } \\
\text { grain, Triticum sp. }\end{array}$ & $\begin{array}{l}\text { SUERC- } \\
78744\end{array}$ & $\begin{array}{l}2263 \\
\pm 35\end{array}$ & $\begin{array}{l}397-205 \\
\text { cal BC }\end{array}$ \\
\hline 9 & 9010 & $\begin{array}{l}\text { Tertiary deposit of } \\
\text { ditch [9009] }\end{array}$ & Charcoal, non-oak & $\begin{array}{l}\text { SUERC- } \\
78745\end{array}$ & $\begin{array}{c}3074 \\
\pm 35\end{array}$ & $\begin{array}{c}1423- \\
1230 \mathrm{cal} \\
\text { BC }\end{array}$ \\
\hline
\end{tabular}

Middle Iron Age: Most of the sites and features discovered across the pipeline corridor were middle Iron Age in date, with a notable concentration of activity in Area 2 and Area $\underline{7}$ (Table 2). Area 2 contained evidence for a series of pits, enclosures, and field systems, probably representing the remains of a small Iron Age settlement. A small assemblage of industrial waste hints at possible smithing within Area 2. A notable find within this area is the double burial of an adult male and child dated to $346-43 \mathrm{cal}$ BC (SUERC-78746) and 381-166 cal BC (SUERC-78738) (Table 3, Figure 3).

Further settlement activity was recorded in Area 7, where several probable enclosure ditches and pits were recorded. Quantities of domestic waste were recovered from the various pits. Samples from two of the pits were radiocarbon dated to 411-208 cal BC (SUERC-78743) and 397-205 cal BC (SUERC-78744) (Table 3, Figure 3). These dates suggest that activity at Area 2 and Area 7 could have been broadly contemporary. In Area 3 a single probable structure, Structure 1, was recorded, and could indicate domestic activity within this area, associated with a series of substantial boundary ditches. It is unclear whether any of the sites persisted beyond the middle Iron Age. There is a general absence of later Iron Age pottery types within the excavated sites, although given the narrowness of the excavated areas, the possibility of later Iron Age activity cannot be ruled out. 
Early to late Roman: Evidence of Romano-British activity in the landscape was much more thinly distributed than that of the middle Iron Age (Table 2). Apart from the Roman road (Akeman Street) and an associated trackway in Area 1, there was a small grouping of ditches and a post-hole in Area 10, the latter containing a collection of hobnails from at least one discarded shoe. These features were sealed beneath a layer of colluvium containing Romano-British pottery, probably deriving from a manure scatter. The distribution of Romano-British tile was also of note in that it was all found in ditch fills in Area 1, whereas the largest pottery assemblages of that period were found in colluvial layers in Area 7 and Area 10. Ceramic material from the pipeline generally dates to the 2nd-4th century AD, although some earlier Roman sherds were noted.

Medieval/post-medieval: Medieval ridge and furrow was noted across the length of the pipeline. In Area 10 a series of plough furrows, and intercutting quarry pits were recorded. Further probable post-medieval quarry pits were recorded in Area 2. Additional medieval or post-medieval furrows were recorded in Area 11 (Table 2). Radiocarbon dating of charred cereal grain from ditch [04006] in Area 4 returned a date of cal AD 680-889 (SUERC-78742) (Table 3, Figure 3), suggesting the ditch was dug or was open during the early medieval period.

\subsection{Summary of excavation results by area}

Explore the excavations by area. 


\subsubsection{Area 1 and Area 13}

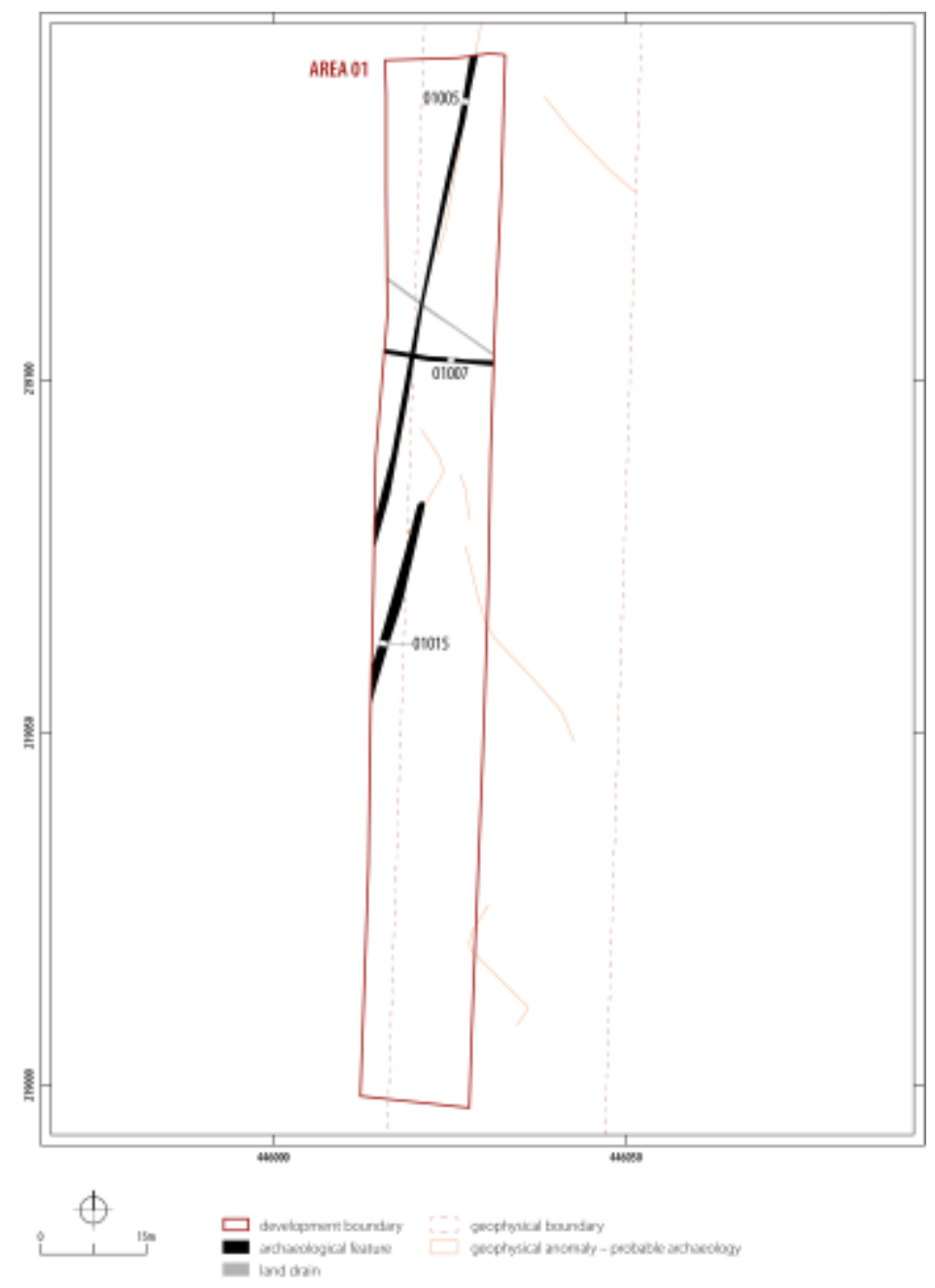

Figure 4: Plan of archaeological features in Area 1

Area 1 contained the remains of a probable trackway and two boundary ditches, dating to the Roman period (Figure 4, Figure 5). These features could be associated with the development of Akeman Street, just to the north in Area 13 (Figure 5). A section of Akeman Street was recorded in Area 13, a targeted excavation area at the northern end of Area 1. Further ditches were identified at and extending beyond the eastern edge of the limit of excavation in the geophysical survey and could represent the remains of a wider field system (Figure 4). 


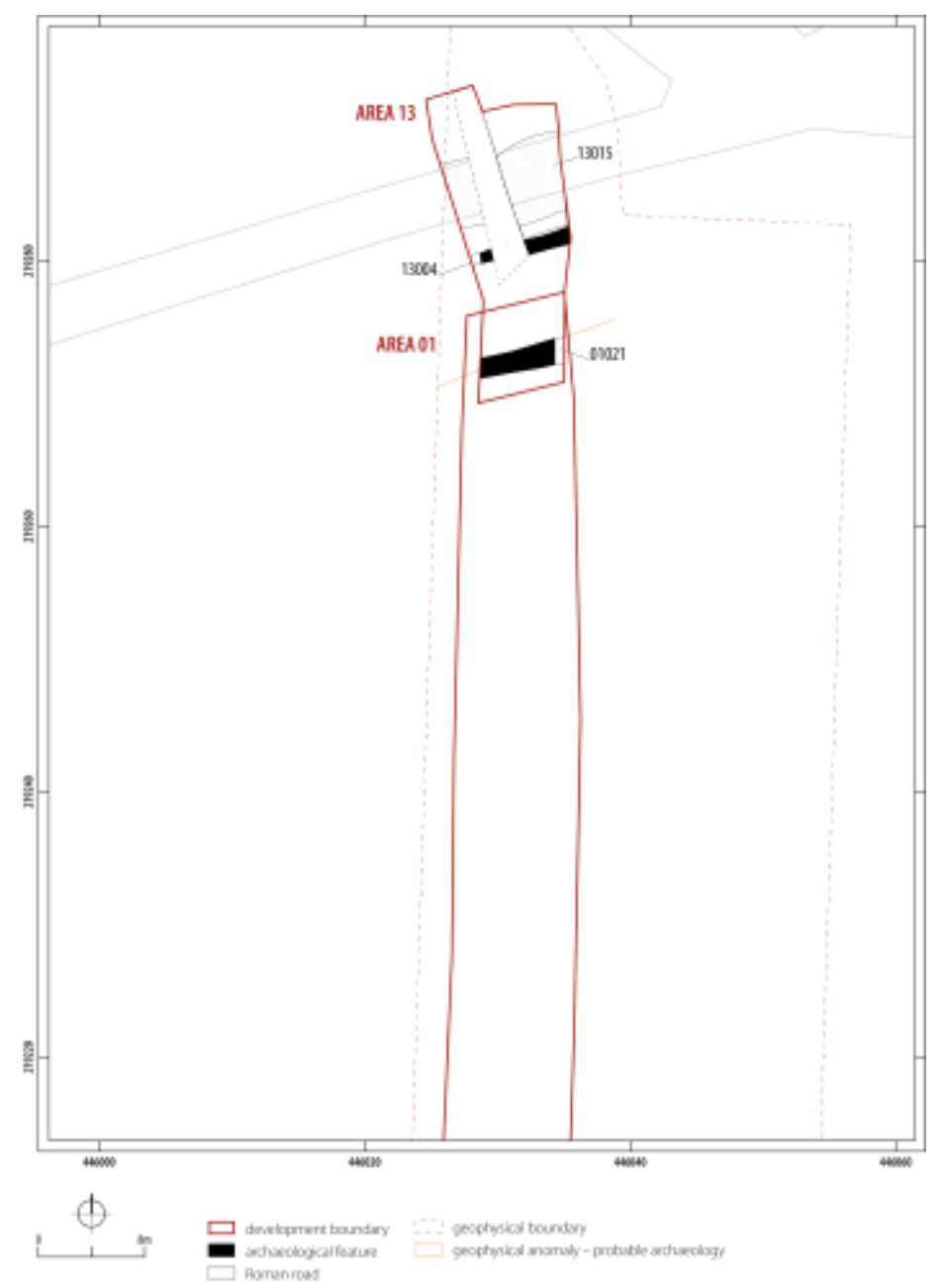

Figure 5: Plan of archaeological features in Area 1/13

\section{Roman trackway and the remains of Akeman Street Roman Road}

The remains of a probable trackway were recorded in Area 1, running north/north-east to south/south-west for about $70 \mathrm{~m}$ (Figure 4), continuing in both directions beyond the edge of the trench. The trackway was defined by two straight flat-based parallel ditches, [01015] and [01005]. The western ditch [01005] extended for 70m and the eastern ditch [01015] for $30 \mathrm{~m}$ in length, the two running roughly $5 \mathrm{~m}$ apart. The latter is partially discontinuous and may have been truncated by ploughing for part of its length. Geophysical survey showed that ditch [01005] extended beyond the limit of excavation but did not appear to extend into the northern part of Area 1 (Figure 4, Figure 5). The ditches may have formed the boundary of a trackway intersecting with and perhaps crossing Akeman Street, recorded in Area 13 to the north (Figure 5).

Ditch [01007] was orientated east to west, intersecting with the trackway ditch [01005], although the precise relationship between the two features is uncertain (Figure 4). The ditch comprised a $135 \mathrm{~m}$ long section, approximately $0.46 \mathrm{~m}$ wide and $0.19 \mathrm{~m}$ deep. It probably represents a shallow drainage ditch.

A small assemblage of Romano-British ceramic building material (19 fragments; $1.3 \mathrm{~kg}$ ), consisting of box flue tile, was recovered from the fills of these ditches. Pottery finds 
were sparse, comprising crumbs of pottery and a residual rim sherd from a middle Iron Age jar from the easternmost trackway ditch, while sherds of grog-tempered grey-ware pottery, were recovered from the western ditch. The latter sherds were generally undiagnostic and not closely datable.

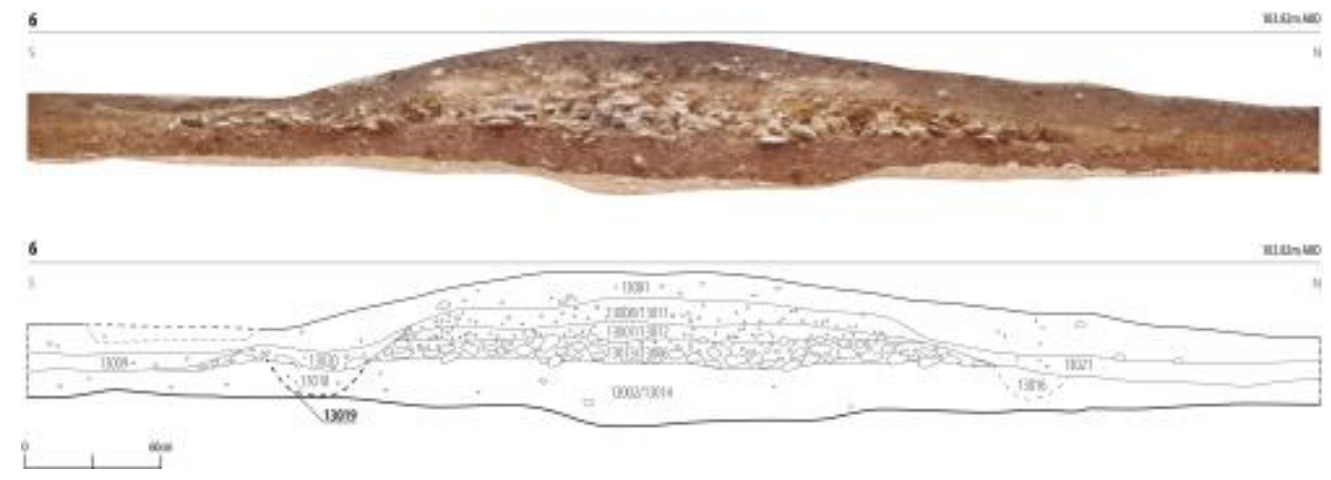

Figure 6: Section through Roman road [13015]

The primary focus of excavation in Area 13 was centred upon the remains of the probable Roman road, [13015]. Excavation across the convex profile of the feature established that the road comprised three elements (Figure 6). The foundation layer of the road $(13006,13013)$ was formed from a $3 \mathrm{~m}$ wide and $0.1 \mathrm{~m}$ deep layer of compacted angular limestone aggregate. This was set above a layer of 'dirty' natural $(13002,13014)$ (Figure 6). This layer was homogeneous and initially thought to be natural, but thinsections subjected to soil micro-morphological analysis indicated that it had been transformed by continuous wet churning perhaps caused by the passage of people, animals, and wheeled transport (see Macphail, this article). It is unclear if this relates to activity associated with the construction of the road or could indicate an earlier trackway underlying this section of Akeman Street (see discussion). The secondary and upper layer of the road was formed by a deposit of angular mid-small limestone rubble suspended within a matrix of fine-grained clay. A similar sequence of construction was recorded during recent excavation of a further section of Akeman Street, near Graven Hill, Bicester (Allen et al. 2020) (Figure 2). As at Area 13, the foundation layer of the road was underlain by a layer of 'dirty' natural with the upper layers comprising redeposited natural and rubble limestone (Allen et al. 2020, 11) (Figure 6).

There were traces of wheel ruts and other signs of wear on the road surface in Area 13. Located to either side were colluvial deposits representing the accumulation of run-off and slumping relating to the erosion of the roadway (Figure 6). Running alongside the southern edge of the road was a shallow drainage ditch [13004], probably associated with the road (igure 5).

A small assemblage of largely undiagnostic Romano-British pottery, ten sherds in total, was recovered during excavation of the road deposits. A minute crumb of South Gaulish samian was recovered from the secondary layer (13021) overlying the Roman road (Figure 6) and would probably have come from a vessel of later 1st or early 2nd century AD date. Given the relatively small size of the sherd and the absence of further dating material, caution should be expressed in dating the construction and the use of the road based on this find (see discussion).

The road is associated with the heavily recut ditch [01021] that runs parallel to it about $9 \mathrm{~m}$ to the south, potentially acting as a further drainage ditch (igure 5). The ditch was 
recorded for $7 \mathrm{~m}$ with evidence for four phases of cuts, all orientated on the same axis, representing regular maintenance of the feature. During the excavation it was thought that a similar ditch might exist on the northern side of the road, but this was not detected during geophysics nor observed after the pipeline corridor had been stripped. From the fill of the ditch, comprising alluvial wash, two sherds of Roman grog-tempered pottery were recovered.

\subsubsection{Area 2}

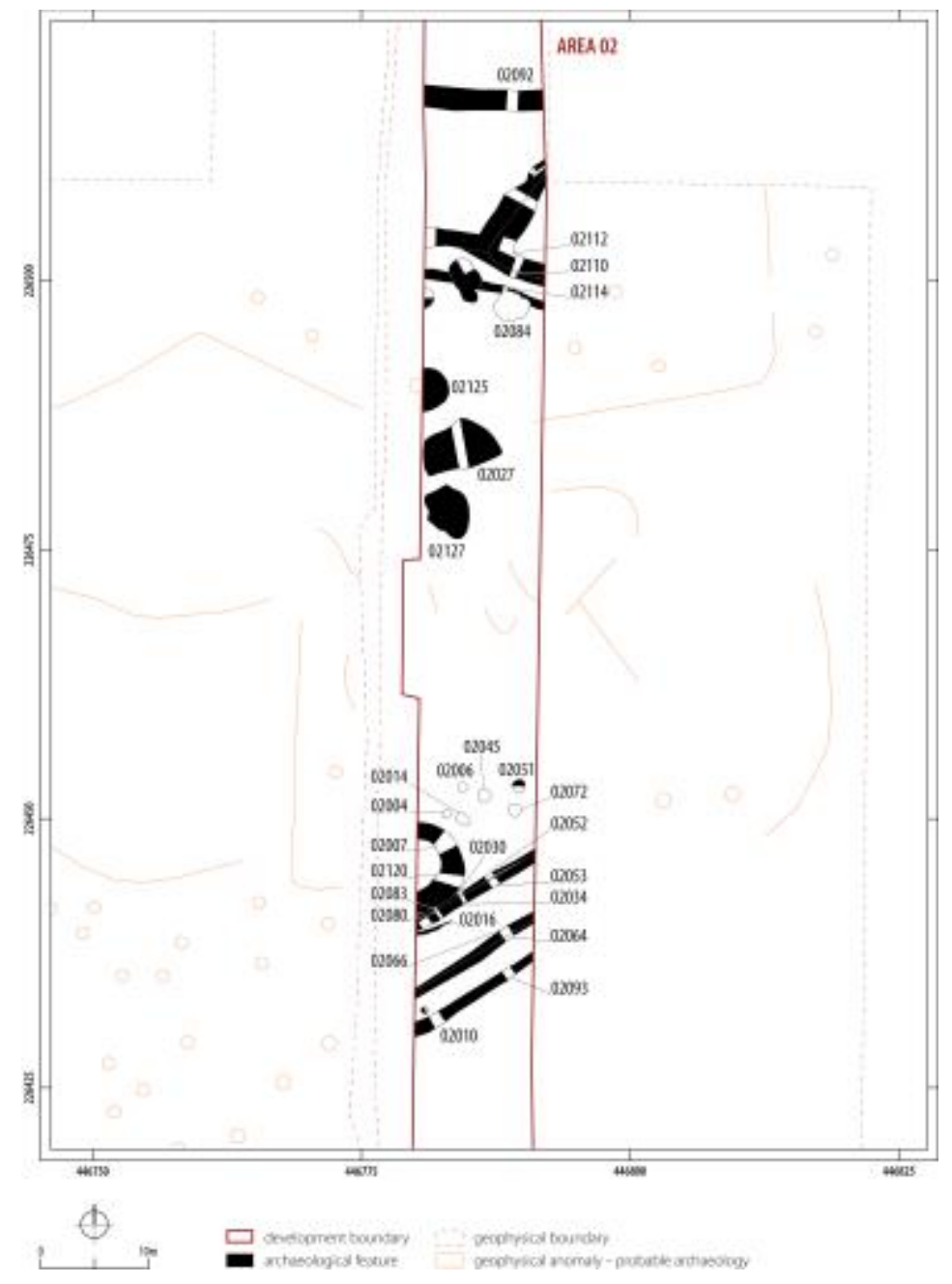

Figure 7: Plan of archaeological features in Area 2

Archaeological remains in Area 2 comprised a series of middle Iron Age ditches running across the centre of the site, a curvilinear ditch, and several pits (Figure 7).

Approximately 535 sherds of pottery were recovered from the fills of the ditches and pits and represent the largest assemblage of pottery from within the development corridor. A series of probable medieval or post-medieval pits were recorded north of these features, with a second group of middle Iron Age pits located to the north. Close to these pits lay three intercutting ditches forming a T-shaped junction, with a further section of ditch just to the north (Figure 7). Geophysical survey of the area showed that these features represent a small part of a larger complex of ditches and pits. Two sections of an Lshaped ditch were identified to the east of the trench defining the corner of a small enclosure or field boundary. Within the 'interior' of this feature were three small pits, with a further two pits recorded to the west, although whether these are natural or man-made 
is unclear. A large cluster of pits were recorded to the west of the corridor, extending in a roughly north-west to south-east line, but again the nature of these is unclear.

\section{Middle Iron Age ditches}

The southernmost archaeological feature within Area 2 comprised a $13 \mathrm{~m}$ long section of a $1.15 \mathrm{~m}$ wide and $0.4 \mathrm{~m}$ deep east to west orientated drainage ditch [02010, 02093] (Figure 7). The ditch was filled with a series of alluvial deposits, which contained a rim from a crudely made jar (Figure 18, P6) and a moderate-sized assemblage of animal bone (c. 134 fragments), mainly cattle and ovicaprids, along with several other species including horse, dog and pig.

Two parallel linear features aligned north-east to south-west, spaced $1.90 \mathrm{~m}$ and $3.70 \mathrm{~m}$ apart, were recorded just to the north of ditch [02010, 02093] (Figure 7). They consisted of a sequence of recut ditches, possibly defining drainage ditches associated with a trackway. The earliest ditches in the sequence were the bowl-shaped gullies [02030, 02052, 02064], which were subsequently filled by a series of alluvial deposits. These were succeeded by a sequence of ditches [02034, 02053, 02066, 02083], just over $1.00 \mathrm{~m}$ wide and up to $0.4 \mathrm{~m}$ deep, with $\mathrm{V}$-shaped profiles. The fills of ditch [02083] contained eight sherds of middle Iron Age pottery and a small assemblage of animal bone. The northernmost of the ditches was recut by ditch [02080, 02016], which contained undiagnostic pottery and a fragment of cattle bone.

Just to the north of the parallel ditches was a substantial curvilinear ditch [02007, 02120], measuring $1.81 \mathrm{~m}$ wide and $0.85 \mathrm{~m}$ deep, which extended approximately $4.5 \mathrm{~m}$ eastwards from the western baulk. The ditch had been recut on at least one occasion and could represent the remains of the corner of an enclosure or boundary ditch, although it is unclear how this feature relates to those identified in the geophysics (Figure 7). Two sherds of Iron Age pottery, and a piece of fired clay were recovered from the fill of the ditch.

Three substantial ditches were recorded $52 \mathrm{~m}$ to the north of the probable enclosure ditch [02007, 02120] (Figure 7). Though represented here by a single context number [02110], these had a complex stratigraphy with numerous recuts, making it difficult to draw a clear distinction between the south-east to north-west and north-east to southwest components. Approximately 72 sherds of middle Iron Age pottery were recovered from the fills of the ditch, including sherds from a wide-mouthed jar (Figure 18, P1), a plain-walled saucepan pot (Figure 18, P2), a body sherd decorated with a single row of shallow impressed dots (Figure 18, P7) and two rims from simple jars (Figure 18, P3, P4). A small assemblage of animal bone, (c. 25 fragments, comprising the remains of primarily ovicaprids and cattle, was recovered from the ditch fills.

Ditch [02092] was situated roughly $5 \mathrm{~m}$ to the north of the $\mathrm{T}$-junction ditches on an eastwest alignment (Figure 7). It was a deep V-shaped ditch, $1.83 \mathrm{~m}$ wide and $0.98 \mathrm{~m}$ in depth. The lower silty clay fills were sealed by a thick layer of charcoal-rich sandy silt, which in turn was sealed by a discrete lens of angular limestone rubble. A small assemblage, 11 sherds in total, of middle Iron Age pottery was recovered from the fill of the ditch, alongside 32 fragments of animal bone. 


\section{Middle Iron Age pits}

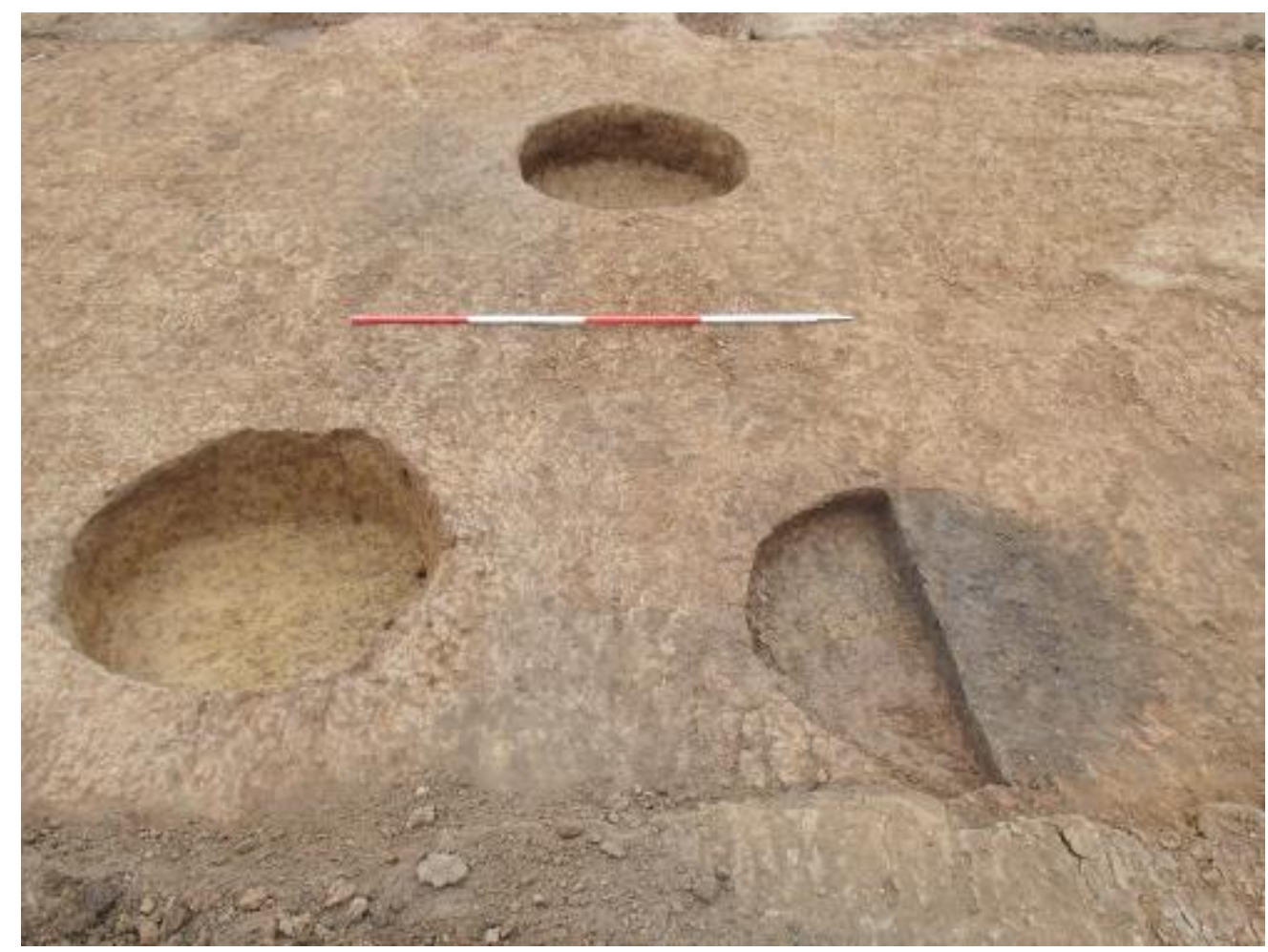

Figure 8: East-facing shot of pits [02045], [02051] and [02072]

Situated immediately to the north-east of ditch [02007, 02120] was a cluster of six subcircular vertical-sided and flat-bottomed pits [02004, 02006, 02014, 02045, 02051, 02072], up to $1.50 \mathrm{~m}$ wide and $0.45 \mathrm{~m}$ deep (Figure 7 , Figure 8 ). The sandy clay fills contained Iron Age pottery and fragments of CBM, fired clay, iron slag, and three fragments of iron sheet, which were recovered from pit [02045]. A large assemblage of animal bone was also recovered from the pits, with most of it deriving from pit [02072]. Several fragments showed signs of butchery, including possible skinning cuts, and canid gnawing. Among the bone from pit [02045] was a possible human tibia from a neonate. Dating of charred cereal grain (Triticum sp.) from the deliberate filling of pit [02045] returned a date of 366-166 cal BC (SUERC-78738) (Figure 3). The precise function of these pits is unclear, as even allowing for a degree of truncation they seem too wide and shallow to have been effective for storage and probably represent shallow waste or extraction pits, which were backfilled with quantities of domestic waste (cf. Lambrick and Allen 2004, 184).

\section{Middle Iron Age double burial}

A large irregularly shaped pit [02084], approximately $3.50 \mathrm{~m}$ in diameter and $0.43 \mathrm{~m}$ deep, was found to cut boundary ditch [02114] to the north (Figure 7). It had steep sides and a broad U-shaped profile. The silty-clay fills contained the disturbed remains of two individuals - an adult male in his early forties (SK2107) and a child of about 12 years old (SK2108). The sub-adult appeared to be lying on its right side with the left arm flexed towards the chest (Figure 9). As the individuals were placed within the same grave cut and were surrounded by the same fill, it suggests that they were interred together and therefore likely to be family members or part of the same group. 


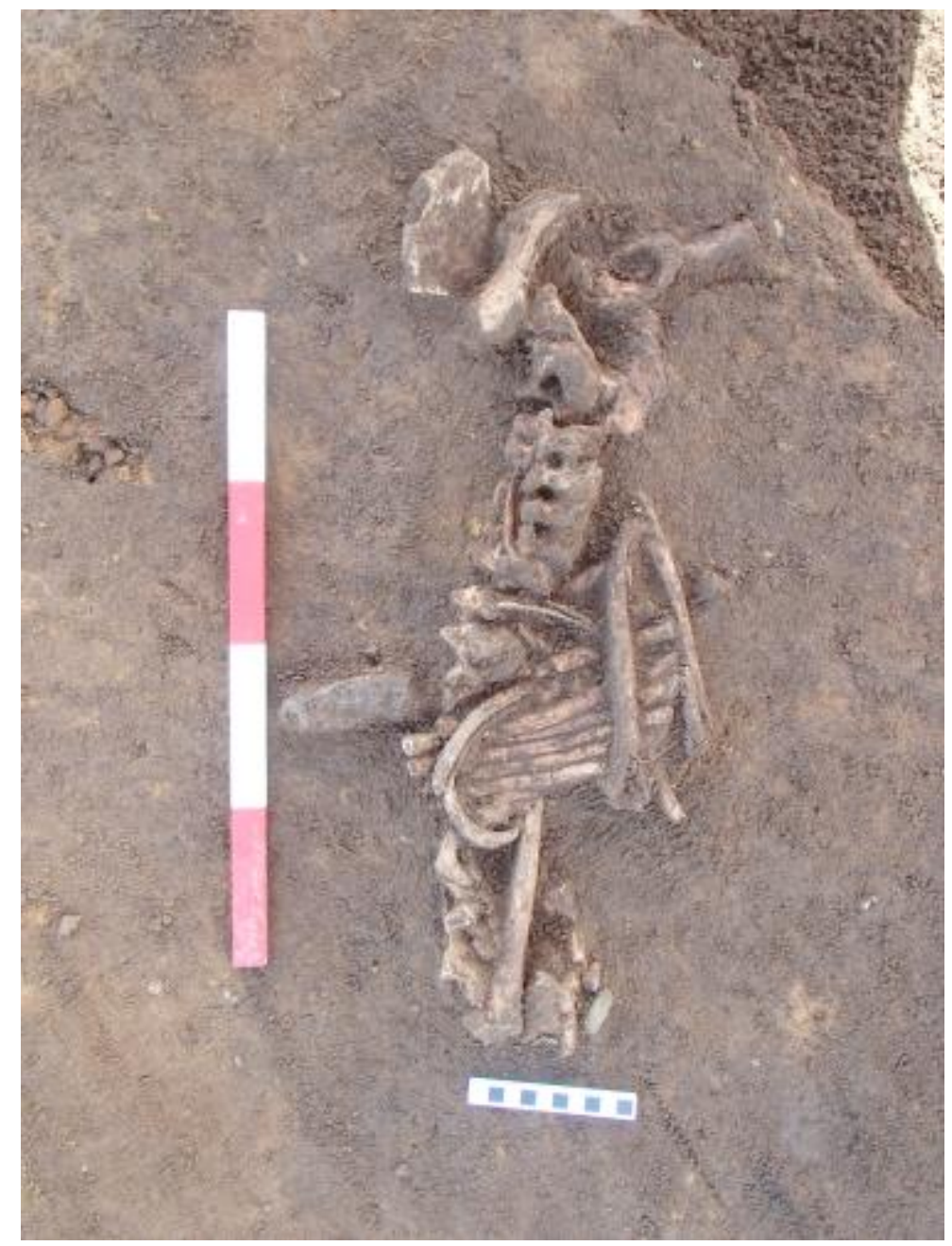

Figure 9: North-east facing shot of SK2108

A moderate assemblage of Iron Age pottery (approximately 43 sherds), a single sherd of Roman pottery, slag and animal bone were recovered from the fill. Among the animal bones were the remains of two young lambs and bones from at least two cats, comprising the remains of the paws, which could represent items of clothing buried with the deceased or some form of cover or wrapping. The lamb bones, in contrast to the other animal remains, may have formed part of the primary funerary rite. Other animal bones in the pit show evidence for extensive butchery and dog gnawing, suggesting that general refuse was incorporated into the backfill of the pit after the disturbance of the human remains. This disturbance also suggests that the burial was marked out in some way.

Other objects recovered from the fill of the burial included a large colourless glass bead and a short length of copper-alloy wire forming a ring or coil. Copper-alloy staining was noted on the right side of the atlas vertebra and the upper end of the right humerus of the child remains, hinting at further copper-alloy objects that may have been robbed. These objects probably represent grave goods associated with the burials, although given the disturbed nature of the burial whether they belong to the adult or child cannot be determined. Radiocarbon dating of the adult remains returned a date of $346-43 \mathrm{cal}$ BC (SUERC-78746) while dating of cereal grain (Triticum sp.) from the fill produced a date of $381-166 \mathrm{cal}$ BC (SUERC-78738), placing the burials in the middle to late Iron Age (Table 3, Figure 3). 


\section{Possible medieval/post-medieval pits}

Three large pits [02027, 02125, 02127] were recorded in the centre of the area and were up to $7.0 \mathrm{~m}$ wide and $0.65 \mathrm{~m}$ deep (Figure 7 ). Fills comprised silty-clays originating from natural infilling. These pits may represent the remains of post-medieval quarry pits.

\subsubsection{Area 3}

In the northern section of Area 3 a large ditch orientated roughly north to south was recorded (Figure 10). To the east of the ditch lay Structure 1, defined by a sub-circular arrangement of post-holes. Two substantial ditch sections were recorded within the south-east section of the area. The remains of further north to south ditches were identified in the geophysics but these are probably plough marks, which are visible from the aerial photos. All features probably date to the middle Iron Age, though the ceramic evidence is minimal.

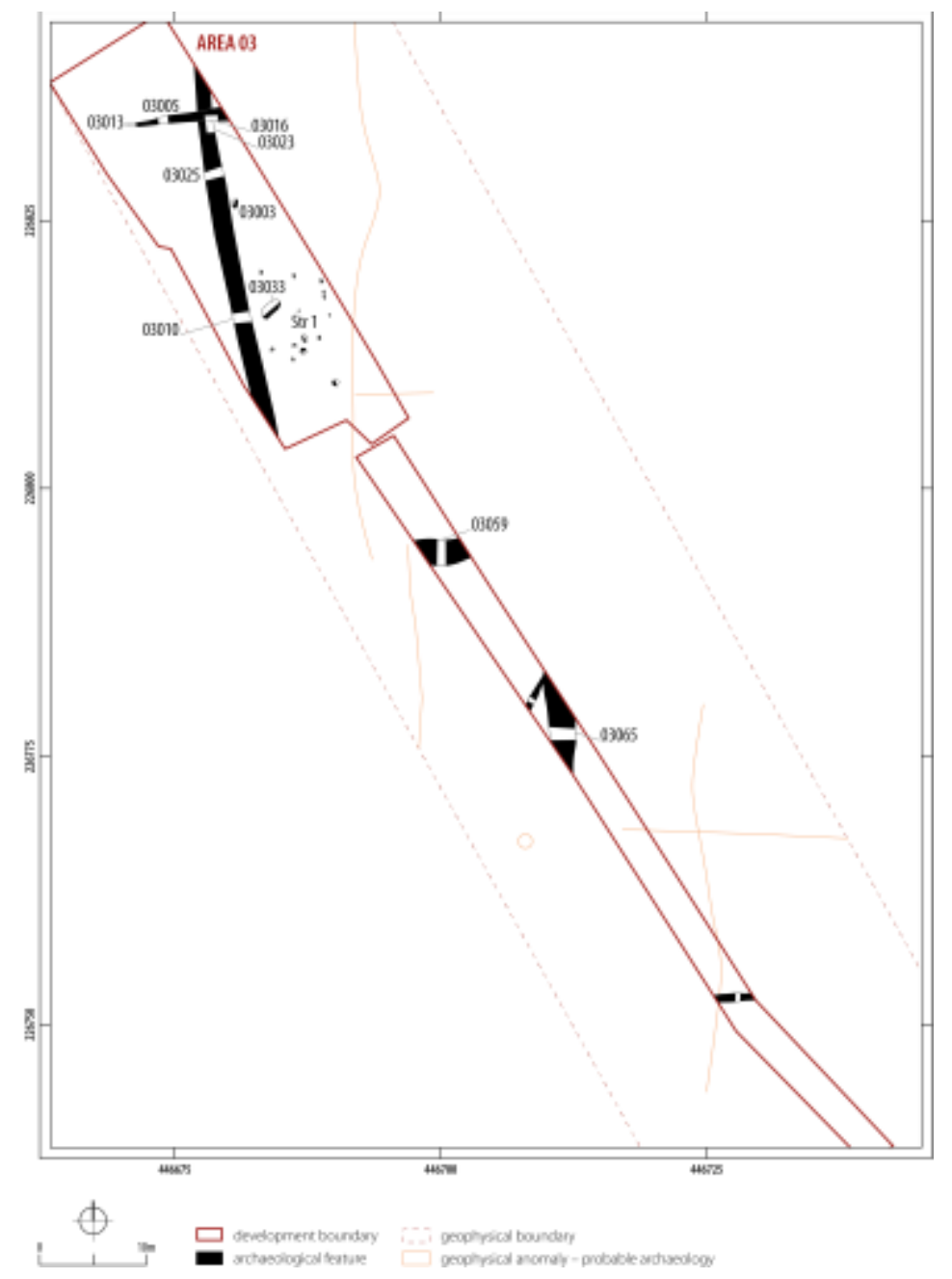

Figure 10: Plan of archaeological features in Area 3

\section{Ditches}

Three large boundary ditches, over $3.2 \mathrm{~m}$ wide and up to $0.80 \mathrm{~m}$ deep, were recorded in Area 3 (Figure 10). In the northern half of Area 3 were the remains of a $36 \mathrm{~m}$ long north 
to south orientated ditch, [03010, 03025, 03023]. Apart from four fragments of animal bone no finds were recovered from the ditch fill. Ditch [03010, 03025, 03023] was truncated by the shallow east to west drainage ditch [03005, 03016, 03013]. No finds were recovered from the ditch. Ditch [03065] comprised a $6 \mathrm{~m}$ long section of a north to south orientated ditch, $2.35 \mathrm{~m}$ and $0.74 \mathrm{~m}$ deep. The ditch was infilled with a series of deposits representing natural silting and the erosion of an associated bank. Frequent inclusions of charcoal, animal bone and a single sherd of middle Iron Age pottery were recovered from the upper fill of the ditch. The third ditch [03059] ran perpendicular to these in an east to west direction and measured $3.2 \mathrm{~m}$ wide and $0.79 \mathrm{~m}$ deep. Within the fill of the ditch was a sequence of sandy clays stemming from the erosion of a probable bank. In the absence of further dating evidence, apart from the single sherd of middle Iron Age pottery from the upper fill of ditch [03065], the precise chronology of these features is unclear. The form and nature of these ditches is suggestive of substantial land boundaries, connected to the delineation of fields or areas of pasture in the Iron Age.

\section{Post-built structure, Structure 1}

Structure 1 was defined by a sub-circular cluster of 13 post-holes, c. $6 \mathrm{~m}$ in diameter, situated to the east of ditch [03010, 03025, 03023] (Figure 10). The post-holes on average were $0.4 \mathrm{~m}$ in diameter and $0.05 \mathrm{~m}$ deep and filled with a series of natural silting deposits; no evidence of post-pipes was recorded. The outer walls of the structure were likely constructed using wattle and daub (Lambrick and Robinson 2009, 135). A shallow bowl-shaped pit [03033], measuring $2.1 \mathrm{~m}$ long by $1.1 \mathrm{~m}$, was recorded at the western edge of Structure 1, and could represent the remains of an internal feature. A single sherd of middle Iron Age pottery was recovered from one of the post-holes. The precise relationship between the possible roundhouse and ditch [03010, 03025, 03023] is unclear.

About $7 \mathrm{~m}$ north of the Structure 1 was a shallow pit [03003], $0.68 \mathrm{~m}$ long by $0.44 \mathrm{~m}$ wide, containing 11 fragments of animal bone, marine shell and four sherds of Iron Age pottery. This could be a refuse pit associated with the structure.

\subsubsection{Area 4}

Six features of archaeological interest were identified in Area 4 (Figure 11). These include a narrow and shallow ditch of possible Iron Age date found on the line of a curvilinear enclosure previously identified by geophysical survey. In one part of the area, there was a large layer of colluvium, up to $0.45 \mathrm{~m}$ deep, containing residual RomanoBritish sherds of pottery. Three plough-truncated ditches and a pit were identified underlying the colluvium. 


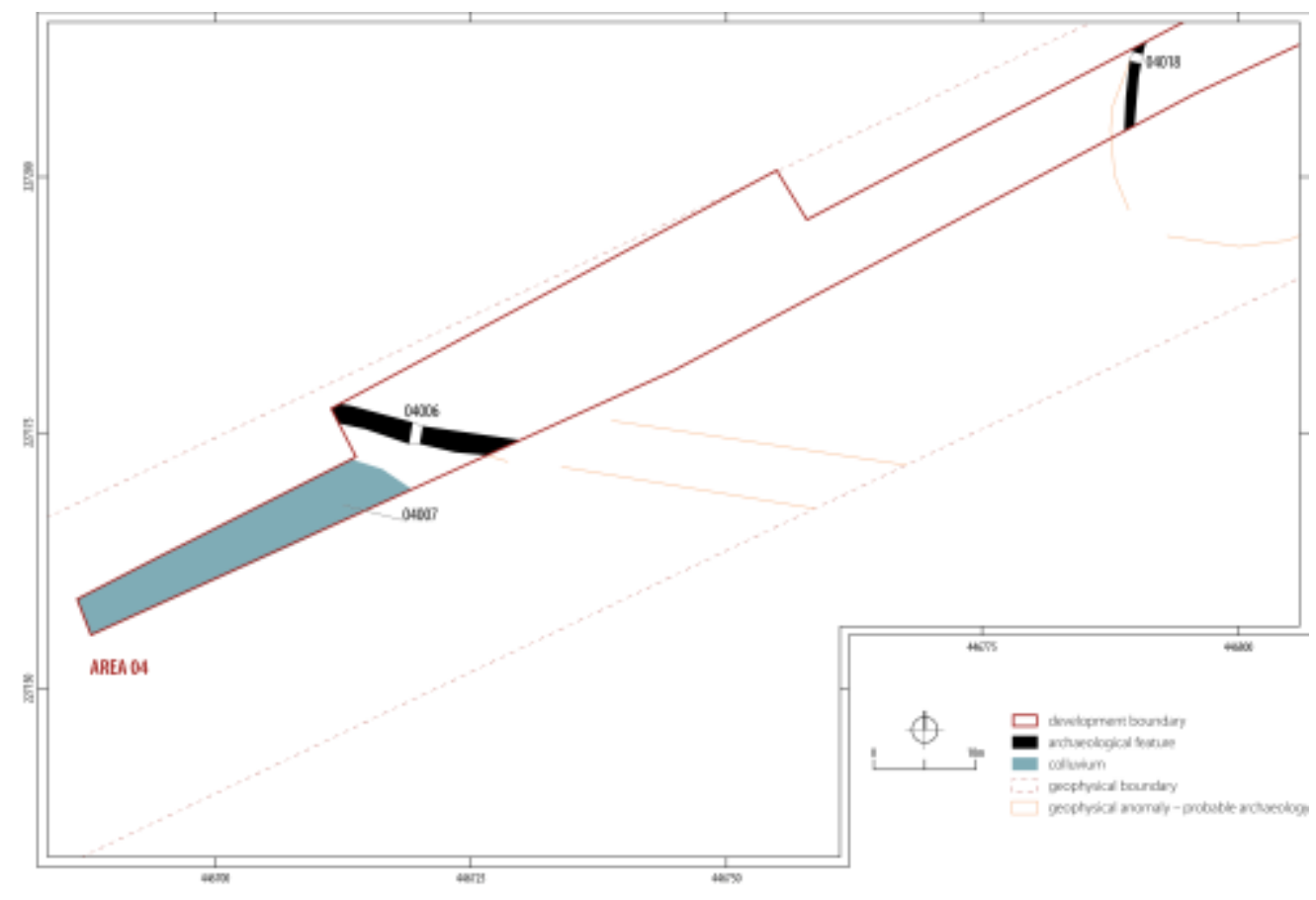

Figure 11: Plan of archaeological features in Area 4

\section{Ditches}

Ditch [04018] aligned north to south was $8.5 \mathrm{~m}$ long and c. $1 \mathrm{~m}$ wide. The ditch forms part of a sub-oval feature identified in the geophysics, which extends beyond the limit of excavation (Figure 11). This feature was just under $20 \mathrm{~m}$ wide and probably represents the remains of a small enclosure. The precise date of the feature is uncertain, though a single sherd of Iron Age calcareous pot was recovered. Ditch [04006], to the south-west, ran roughly east to west and measured $18 \mathrm{~m}$ long, $1.74 \mathrm{~m}$ wide and $c .0 .78 \mathrm{~m}$ deep, with a $\mathrm{V}$-shaped profile. The fill of the ditch contained a layer of loose silty sand, possibly deriving from the erosion of the bank. The ditch was detected extending to the east on the geophysics and may have formed part of a larger field boundary. A small quantity (1g) of iron slag and a possible flint scraper was recovered from ditch [04006]. A sample of charred cereal grain (Triticum sp.) from the primary fill of the same ditch returned a radiocarbon date of cal AD 680-889 (SUERC-78742) (Table 3, Figure 3), suggesting that it may have been open or dug in the early medieval period.

To the south of ditch [04006] was a spread of colluvium [04007], comprising a 32m long and $4.4 \mathrm{~m}$ wide layer of loose silty sand, from which two residual sherds of Roman pottery were recovered.

\subsubsection{Area 5}

Excavation of Area 5 revealed four features of archaeological interest, two U-shaped ditches and two pits, one of which was truncated by ditch [05011]. One of the ditches [05005] might correlate to one side of an enclosure detected by geophysical survey (Figure 12). No finds or datable material were recovered from any of the features and so they are not described here in any detail. 


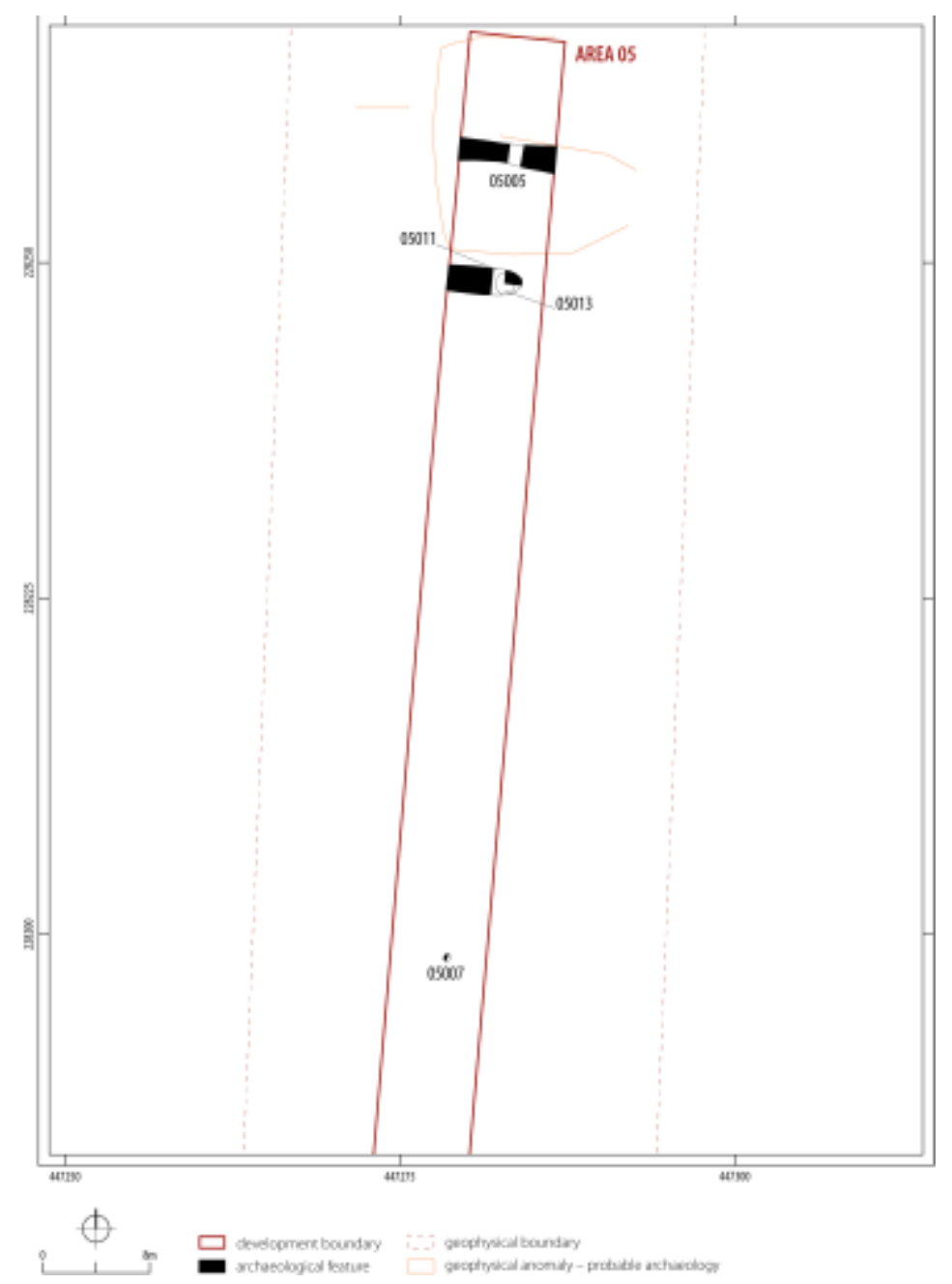

Figure 12: Plan of archaeological features in Area 5

\subsubsection{Area 7}

Within Area 7, 26 archaeological features were recorded, comprising several pits and ditch sections, representing the remains of a small settlement (Figure 13). These were predominantly located within the eastern extent of the trench, with the pits forming a dense cluster encircled to the west by a series of small ditches or gullies. Artefactual data suggest that all the cut features are Iron Age in date. To the east of the corridor geophysical survey identified the remains of several ditches and pit features, which could represent an extension of the excavated features. In the north-west corner was an extensive spread of material in a natural hollow [07030], possibly representing the remains of a heavily disturbed midden. 


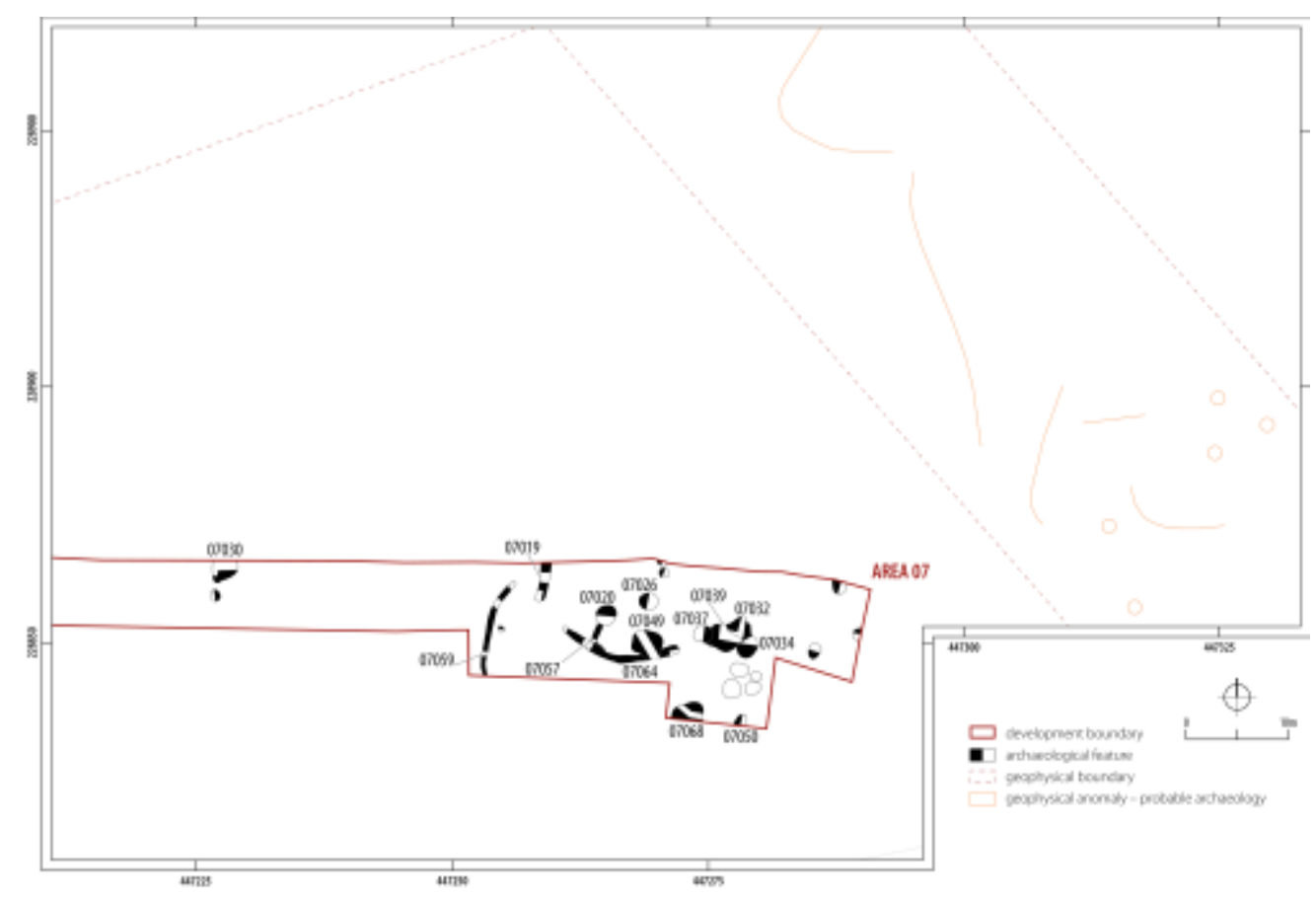

Figure 13: Plan of archaeological features in Area 7

\section{Ditches}

Ditch [07057] comprised a 12.4m curvilinear ditch, recutting the earlier ditch [07064], which was visible as a steep-sided U-shaped cut approximately $0.4 \mathrm{~m}$ wide and $0.28 \mathrm{~m}$ deep. Ditch [07057] followed a similar alignment to ditch [07064] and was approximately $0.8 \mathrm{~m}$ wide and $0.2 \mathrm{~m}$ deep. Ditch [07059] to the west comprised a $10 \mathrm{~m}$ section of a $\mathrm{V}$ shaped ditch, $0.6 \mathrm{~m}$ wide and $0.4 \mathrm{~m}$ deep, terminating at its northern extreme in a shallow U-shaped cut.

Around 94 sherds of middle Iron Age pottery were recovered from ditch [07057] with a further 34 sherds recorded from ditch [07059]. Alongside these, fragments of fired clay, iron slag, and burnt and unburnt animal bone were recovered. A similar assemblage was found in ditch [07019] which could be the terminus of a third curvilinear feature (Figure $\underline{13}$ ). These ditches could represent the remains of small stock or domestic enclosures.

\section{Pits}

A spread of eight small to medium sized pits were recorded across the eastern half of the trench (Figure 13). These ranged in diameter from 1 to $2 \mathrm{~m}$ and were between 0.1 and $0.4 \mathrm{~m}$ in depth. Pit [07026] had a bell-shaped profile and contained 31 sherds of middle Iron Age pottery and fragments of animal bone, including pieces with evidence of canid gnawing. Further sherds of middle Iron Age pottery alongside fragments of animal bone were recovered from some of the other pits. As noted previously, the relatively shallow nature of these pits may indicate these features were not, except for the bellshaped pit [07026], intended to function as storage pits. A small quantity of barley grains were recovered from the fill of pit [07026].

A sequence of four large intercutting steep-sided sub-circular pits [07032, 07034, 07037, 07039], averaging 2-3m in diameter and up to 0.30 deep, were recorded in the eastern half of Area 2. A medium-sized assemblage of middle Iron Age pottery (c. 21 sherds) 
alongside a quantity of animal bone, primarily ovicaprids or cattle, were recovered from the fills of the pits. A hobnail of possible Romano-British date, thought to be intrusive, was recovered from pit [07034].

West of these lay the remains of a steep-sided $3.00 \times 0.95 \times 0.60 \mathrm{~m}$ sub-rectangular pit [07049], containing stone rubble and two sherds of middle Iron Age pottery. A second pit [07050] with steep near-vertical sides was investigated at the southern limit of excavation. It was $0.7 \mathrm{~m}$ deep, containing 92 sherds of middle Iron Age pottery together with fired clay, copper-alloy fragments, burnt and unburnt animal bone, charred grain and charcoal.

Fifteen further pits, up to $2 \mathrm{~m}$ in diameter and $0.40 \mathrm{~m}$ deep, were excavated across the area and contained quantities of domestic debris. Again, most of the pits contained middle Iron Age pottery with fired clay fragments and animal bone. The animal bone assemblage mostly comprised ovicaprid remains, although fragments from cattle, and a possible horse rib were noted. Several fragments of bone showed evidence of canid gnawing. Pit [07020] and [07068] contained most of the Iron Age pottery, with 67 sherds recovered from the fill of pit [07068]. Among these were a saucepan-style vessel and two simple rims from jars (Figure 18, P13, P14, P15)

\section{Romano-British colluvial layer}

A sub-oval spread of loose silty sand, infilling a natural hollow [07030], was situated in the west of Area 7 (Figure 13). It was about $2.67 \mathrm{~m}$ in diameter by $0.10 \mathrm{~m}$ deep. A small assemblage of 16 sherds of early Romano-British pottery and a single sherd of middle Iron Age pottery were recovered from this layer, which could represent the remains of a heavily disturbed midden.

\subsubsection{Area 9}

Only two features of archaeological interest were identified in Area 9. Across the northern half of the site ran a post-medieval or modern field drain [09003]. Further south, geophysical survey had previously identified a north-west to south-east orientated enclosure/boundary ditch that turned sharply to the south-west within the development corridor (Figure 14). This was located on the ground and a segment through it was excavated [09009]. The ditch was $2.70 \mathrm{~m}$ wide by $1.50 \mathrm{~m}$ deep with a V-shaped profile. Seven fills of sandy silts and clays were recorded within the ditch. Fragments of sandstone slabs, rubble, fired clay, middle Iron Age pottery, unburnt animal bone and marine shell were recovered from the feature. Charcoal from the tertiary fill of the ditch was dated to 1423-1230 cal BC (SUERC-78745) (Figure 3). A single pit [09007] containing dense charcoal material from a fire was excavated nearby, but the fills contained no datable artefacts. The geophysical survey had also identified a cluster of nine possible archaeological features immediately to the north-west of the enclosure/boundary ditch, although the precise nature of these is unclear. 


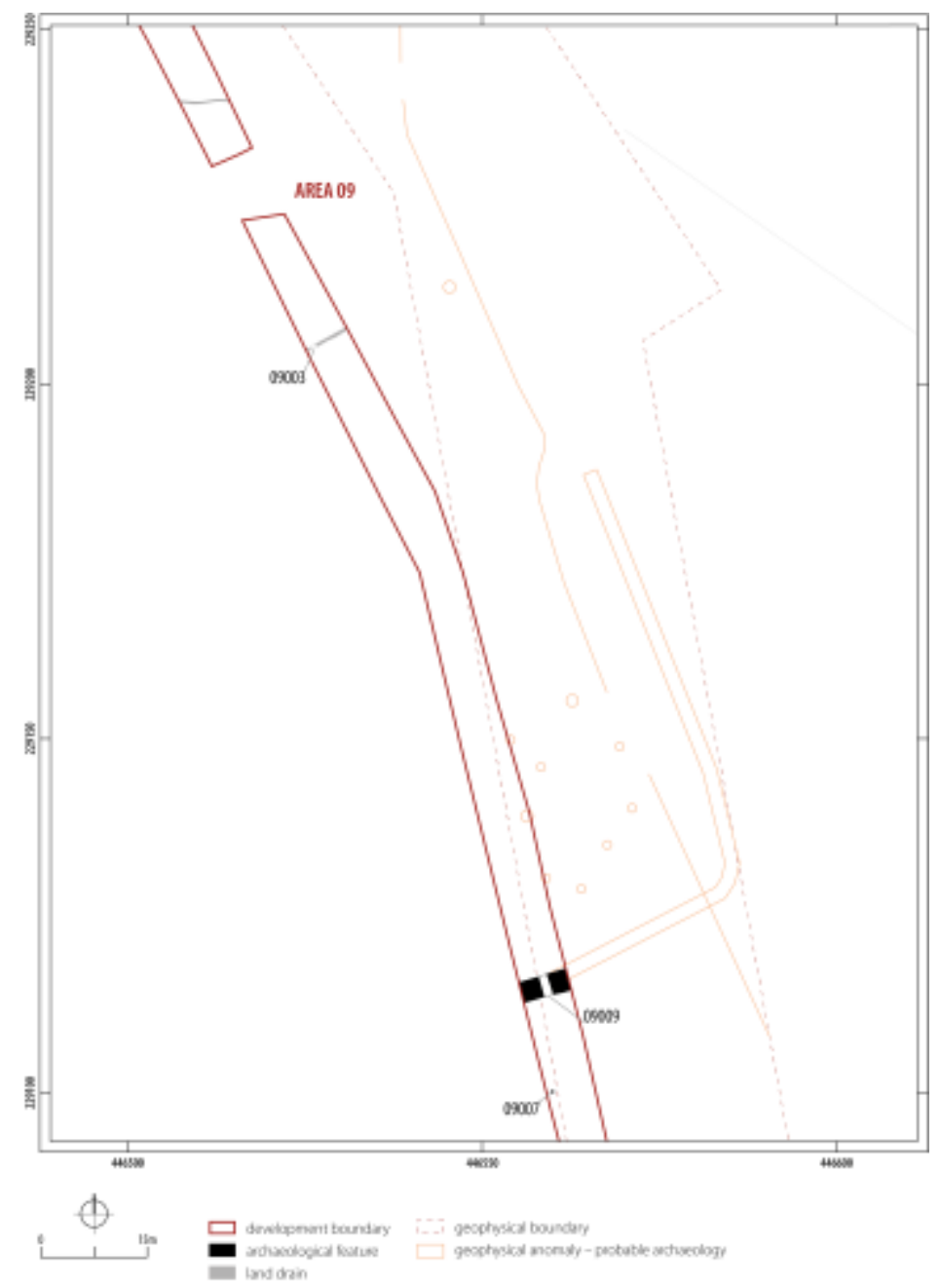

Figure 14: Plan of archaeological features in Area 9

\subsubsection{Area 10}

In total 30 features of archaeological interest were identified, predominantly associated with Romano-British, medieval and post-medieval agricultural/aggregate extraction activities (Figure 15). A single sherd of early Bronze Age Beaker pottery was recovered from this area, hinting at an earlier phase of activity. An extensive array of geophysical features were noted, primarily concentrated in the southern half of the site, extending to the east and west of the site. Identified features include several further ditches, pits and possible spreads. 


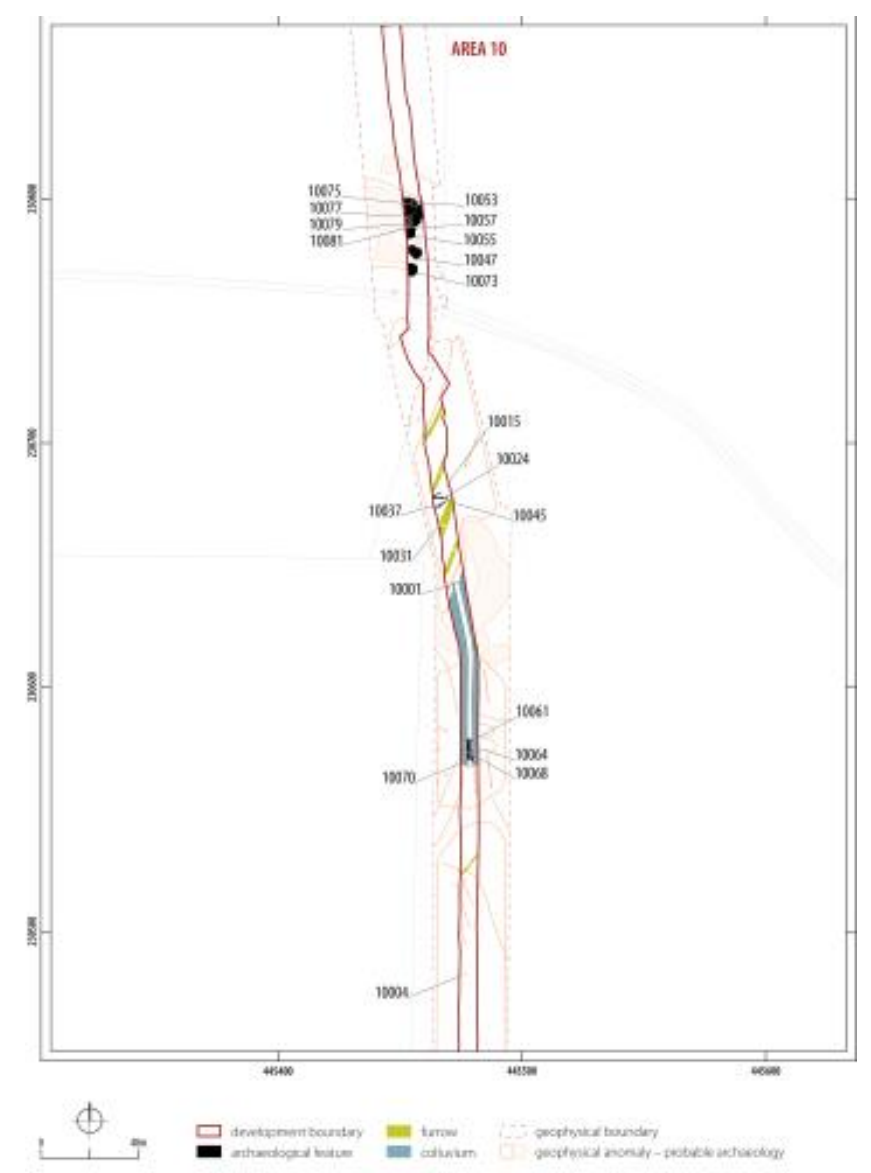

Figure 15: Plan of archaeological features in Area 10

\section{Prehistoric/Iron Age Features}

A small cluster of heavily truncated features was recorded within the central extent of Area 10. Among these were two very shallow features $[10015,10045]$ that may represent the remains of post-holes. Within the fill of the features were stones that may represent packing. The remains of at least five shallow ditches were recorded within the area and likely represent the remains of agricultural drainage ditches. Dating evidence for these features was limited to a single residual sherd of heavily abraded early Bronze Age Beaker pottery from the sandy-silt fill of ditch [10024].

\section{Romano-British features}

A silty-clay colluvial spread (10001) was recorded for a stretch of $74 \mathrm{~m}$ in the southern part of the mitigation area. It was up to $0.20 \mathrm{~m}$ deep in places, sealing the ditches described above. A small assemblage, comprising 17 sherds of 1 st to 4th century AD Romano-British pottery, was found within it - possibly representing a manure scatter that has been washed downhill rather than deposited in situ.

Under the colluvium was a dense cluster of east-west aligned inter-cutting ditches [10061, 10064, 10068, 10070], up to $2.50 \mathrm{~m}$ wide and $0.60 \mathrm{~m}$ deep, with evidence of frequent recutting. It is unclear if these features are the same as those identified in the geophysics to the east (Figure 15). A small assemblage of Romano-British pottery dating to the 1 st to 4 th century $A D$, alongside fragments of industrial waste and cattle bone, 
was recovered from the fills. Situated $39 \mathrm{~m}$ to the south of these drainage ditches lay an $11 \mathrm{~m}$ section of a north-west to south-west ditch, $0.93 \mathrm{~m}$ wide and $0.24 \mathrm{~m}$ deep.

Post-hole [10004] was filled with a charcoal-rich clay deposit containing an assemblage of 64 hobnails (perhaps all from one or two shoes), small CBM fragments, iron slag and burnt animal bone. This was a small, isolated feature situated about $30 \mathrm{~m}$ to the south of the southern edge of the colluvial layer. It is unclear if this represents a waste deposit, or perhaps represented a structured deposit (cf. Smith et al. 2018, 190).

\section{Medieval/post-medieval features}

Situated in the northern extent of the excavation area were a sequence of cut features $[10047,10053,10055,10057,10073,10075,10077,10079,10081]$ relating to postmedieval quarrying activity. All the pits were filled by silty clay deposits, several of which contained animal bone, glass and 18th to 19th-century pottery. Other medieval/postmedieval features included a series of four parallel south-west to north-east linear features representing the remains of ridge and furrow agriculture.

\subsubsection{Area 11}

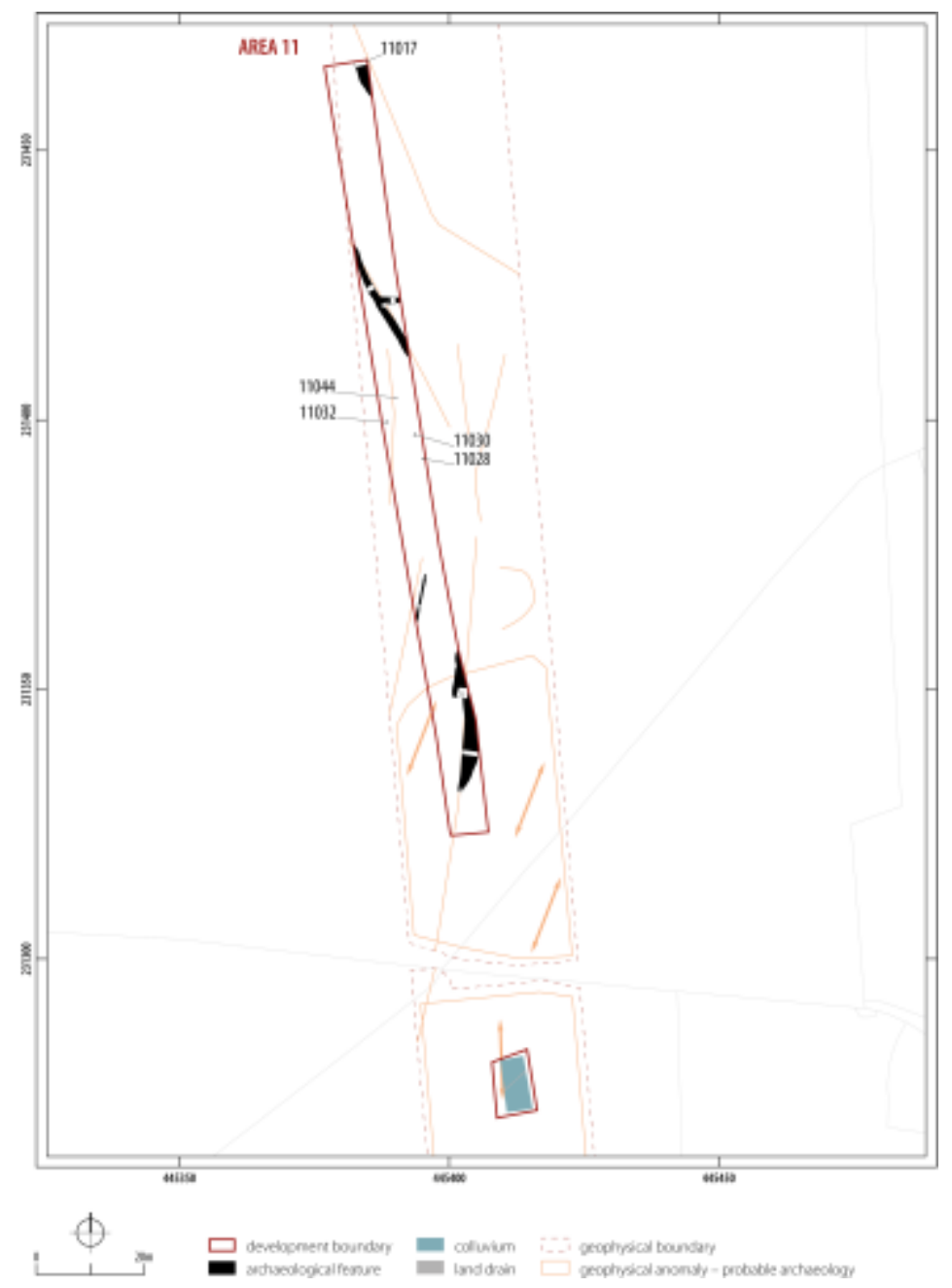

Figure 16: Plan of archaeological features in Area 11 
Several ditches and four post-holes were excavated, but none could be securely dated by their inclusions (Figure 16). Situated in the north-eastern corner of the excavation was ditch [11017], which was identified through geophysical survey extending to the north-west and south-east, likely defining a larger field boundary. Other ditches in the excavated area are probably post-medieval field boundaries. Situated within the central extent of Area 11 were a series of four heavily truncated post-holes [11044, 11032, $11030,11028]$. No artefactual material was recovered from these features, and they could represent the remains of fence lines associated with the post-medieval use of the area.

Table 4: Summary of dated pottery recovered by area (no. sherds)

\begin{tabular}{|c|c|c|c|c|c|c|c|}
\hline Area & $\begin{array}{c}\text { Pottery } \\
\text { (Early pre) }\end{array}$ & $\begin{array}{l}\text { Pottery } \\
\text { (IA) }\end{array}$ & $\begin{array}{l}\text { Pottery } \\
\text { (Rom) }\end{array}$ & $\begin{array}{l}\text { Pottery } \\
\text { (Med) }\end{array}$ & $\begin{array}{l}\text { Pottery } \\
\text { (PM) }\end{array}$ & $\begin{array}{l}\text { Pottery } \\
\text { (Mod) }\end{array}$ & $\begin{array}{l}\text { Grand } \\
\text { Total }\end{array}$ \\
\hline 1 & & 1 & 3 & & 2 & 2 & 8 \\
\hline 2 & & 535 & 2 & & & & 537 \\
\hline 3 & & 8 & & & 1 & & 9 \\
\hline 4 & & 1 & 2 & & & & 3 \\
\hline 7 & & 258 & 18 & & & 1 & 277 \\
\hline 9 & & 9 & & & & & 9 \\
\hline 10 & 1 & & 28 & 2 & 11 & 6 & 48 \\
\hline 11 & & & & 1 & 5 & 11 & 17 \\
\hline 12 & 1 & & & & 6 & & 7 \\
\hline 13 & & & 11 & & & & 11 \\
\hline TOTAL & 2 & 812 & 64 & 5 & 25 & 20 & 926 \\
\hline
\end{tabular}

\subsubsection{Area 12}

The excavated features within Area 12 comprised a series of linear features, defining the outline of a probable enclosure or boundary ditch, as well as a series of six medieval or post-medieval furrows (Figure 17). A large ditch [12017] was found to cross the mitigation area from north-east to south-west. It was $3.61 \mathrm{~m}$ wide by $1.15 \mathrm{~m}$ deep. A single patinated Neolithic/early Bronze Age flint flake was recovered from the fills. About $100 \mathrm{~m}$ to the north, a similar stretch of ditch [12006] was found orientated north-west to south-east. It was $2.57 \mathrm{~m}$ wide by $0.75 \mathrm{~m}$ deep and $U$-shaped in profile. A single sherd of early Bronze Age grog-tempered beaker ware was found in the fill along with two smaller crumbs. It is possible, as was the case in Area 10, that this sherd is residual. The ditch appears to form a large curving enclosure or boundary ditch, corresponding to anomalies detected by geophysical survey. 


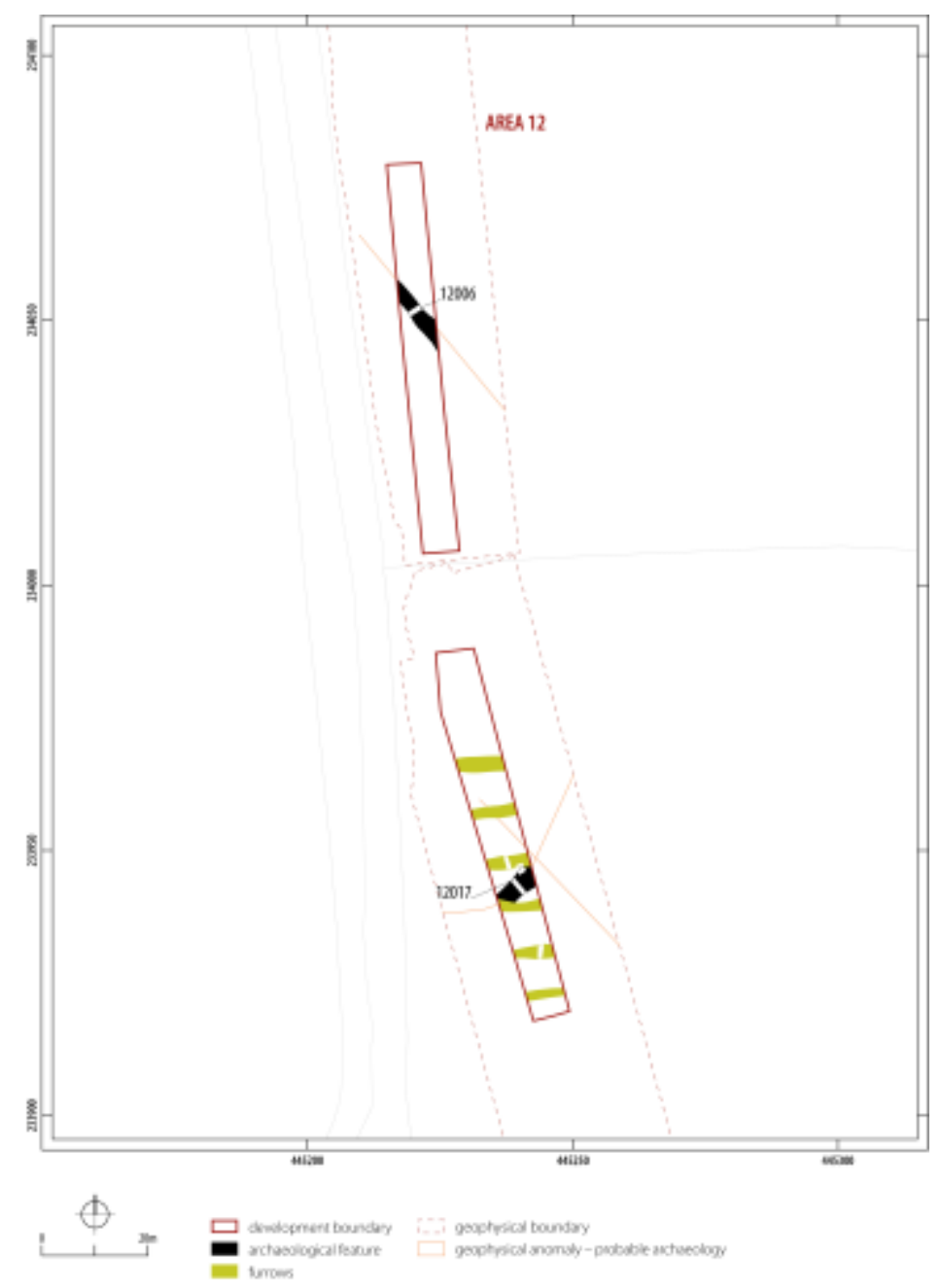

Figure 17: Plan of archaeological features in Area 12

\section{Summary of Finds and Environmental Data}

\subsection{Pottery by Jane Timby}

The archaeological work at Angelinos Pumping Station resulted in the recovery of $c .926$ sherds of identifiable pottery, accompanied by $c$. 355 small crumbs collectively weighing c. $11.2 \mathrm{~kg}$. The assemblage largely dates to the middle Iron Age, accompanied by lesser quantities of earlier prehistoric, Roman, medieval and post-medieval material (Table 4). The pottery is in mixed condition, with some large sherds but also many fragmented pieces owing to the nature of the fabrics. The Roman material is particularly fragmented and abraded. 
Table 5: Quantification of Iron Age pottery from across the pipeline

\begin{tabular}{|c|c|c|c|c|c|c|c|}
\hline $\begin{array}{l}\text { Fabric } \\
\text { code }\end{array}$ & Description & No. & No. \% & Wt (g) & $\mathbf{W t} \%$ & EVE & $\begin{array}{c}\text { EVE } \\
\%\end{array}$ \\
\hline $\mathrm{SH} 1$ & coarse fossil shell & 215 & 26.48 & 3880.5 & 38.83 & 0.81 & 30.92 \\
\hline SHLI1 & shell and limestone sparse & 257 & 31.65 & 1945.5 & 19.47 & 0.22 & 8.40 \\
\hline SHLI2 & shell and limestone finer & 26 & 3.20 & 190 & 1.90 & 0.29 & 11.07 \\
\hline SHLI3 & shell and limestone denser & 60 & 7.39 & 770 & 7.71 & 0.4 & 15.27 \\
\hline SALI & sandy with shell & 238 & 29.31 & 3017 & 30.19 & 0.71 & 27.10 \\
\hline SAFSH & fine sandy with limestone & 2 & 0.25 & 38 & 0.38 & 0.06 & 2.29 \\
\hline SAOR & sandy with organic & 1 & 0.12 & 5 & 0.05 & 0 & 0.00 \\
\hline SA1 & sandy & 6 & 0.74 & 88 & 0.88 & 0.05 & 1.91 \\
\hline SA2 & glauconitic sandy & 1 & 0.12 & 7 & 0.07 & 0 & 0.00 \\
\hline SAF & fine sandy & 5 & 0.62 & 49 & 0.49 & 0.08 & 3.05 \\
\hline \multirow[t]{2}{*}{ MAL RE A } & $\begin{array}{l}\text { Malvernian rock-tempered } \\
\text { (Peacock 1968) }\end{array}$ & 1 & 0.12 & 3 & 0.03 & 0 & 0.00 \\
\hline & TOTAL & 812 & 100.00 & 9993 & 100.00 & 2.62 & 100.00 \\
\hline
\end{tabular}

\subsubsection{Early prehistoric}

The prehistoric assemblage comprises two sherds of probable Beaker pottery. One is a grog-tempered sherd that was recovered from ditch [12006] along with two crumbs; the other, a sandy ware with sparse voids from calcareous inclusions from ditch [10024].

\subsubsection{Middle Iron Age}

\section{Assemblage composition: fabrics and forms}

Approximately $87.7 \%$ of the assemblage appears to date to the middle Iron Age period. The bulk of the finds came from Area 2 and Area 7 with small amounts from Area 1 , Area 3 and Area 9 (Table 4).

Calcareous wares (SH1, SHLI1-3) form the largest group of fabrics, accounting for $68 \%$ of the later prehistoric sherds by sherd count and weight (Table 5). Most of the vessels are jar forms including a large storage-type jar (Figure 18, P15), barrel or globularbodied jars (Figure 18, P1, 3, 4, 7, 10-11, 14) and ovoid jars with undifferentiated rims (Figure 18, P6) and, more rarely, bowls (Figure 18, P8). Sandy with shell/limestone wares (SALI, SAFSH) account for $29.3 \%$ of the later prehistoric assemblage by count. A significant proportion of this is taken up by multiple sherds from one large vessel (Figure 
$\underline{18}, \mathrm{P} 5)$. Less common, with only two sherds, is a much finer sandy fabric where the quartz is not macroscopically visible, with rare inclusions of shell or limestone (SAFSH). This latter ware includes a globular jar (Figure 18, P9). Sandy wares (SA1-2; SAF) form a moderately small group of material. SA1 is a medium to fine black sandy ware with a red-brown core and includes one saucepan-style vessel (Figure 18, P2). The single body sherd of SA2 is a glauconitic sandy ware, while SAF is a very fine, black sandy ware with occasional ferruginous grains. The latter was used to make another wellburnished saucepan-style pot (Figure 18, P13).

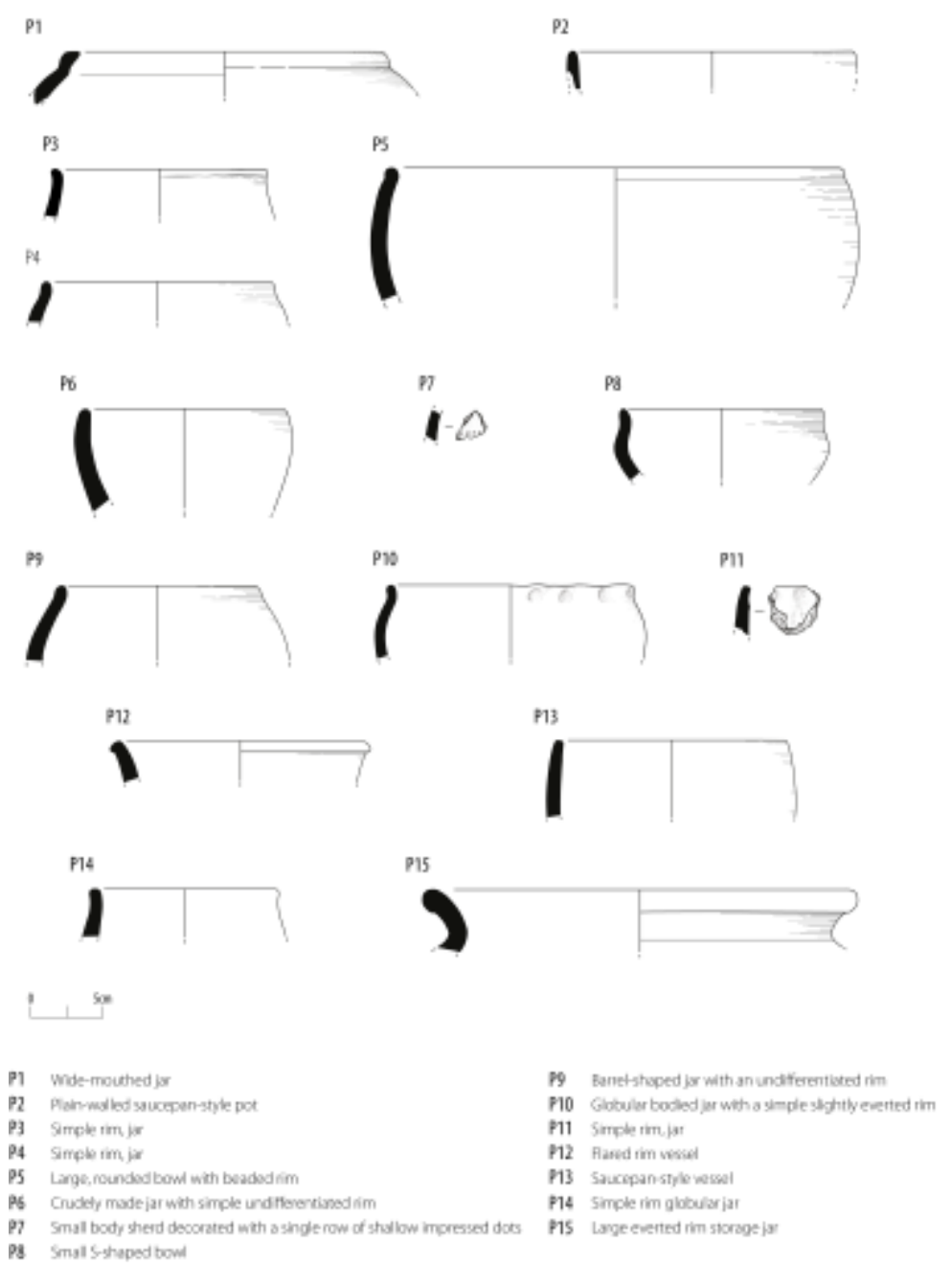

Figure 18: Iron Age pottery from the pipeline

Featured sherds are extremely sparse. There are 45 rims among the later prehistoric assemblage from a minimum of 33 vessels. Most of these are from plain vessels, which have no apparent surface finish although a few vessels have been burnished. The only decorated piece is a small sherd from ditch [02110] with a single horizontal line of small impressed dots (Figure 18, P7). There are at least two saucepan-style pots, one from ditch [02112] in a black sandy ware (Figure 18, P2) and one from pit [07068] with a highly burnished black finish (Figure 18, P13). Pit [02014] produced several sherds from a very large wide-mouthed jar or bowl (Figure 18, P5). Evidence of use can be seen in the presence of several examples of carbonised residue or sooting. Some sherds show voids on the interior surface where the calcareous inclusions have leached out from use. 


\section{Inter-site variation}

Within this group there were notable variations among the sites, especially between Area 2 and Area 7, where the larger assemblages facilitate closer analysis. While a similar number of different fabrics were recorded at both sites, there were differences in the overall composition. In Area 2 the primary fabrics comprised SALI, SH1 and SHL1, while in Area $7 \mathrm{SH} 1$ and SHLI1 formed the primary fabric groups. A high proportion of the recorded sherds from Area 2 were in fabric SALI, although this number is slightly exaggerated as several sherds stemmed from a single large storage jar. Fabric SALI was not recorded elsewhere across the scheme and could reflect different tempering strategies among the sites or access to different sources of clay. Given the ubiquitous nature of the wares and the limitations in the dataset it cannot be determined if these also reflect differences in chronology.

Regarding vessel forms in Area 2 and Area 7, both sites, where forms could be identified, showed a preference for jars, probably employed for storage on site.

\section{The wider ceramic picture}

In the Upper Thames Valley to the west and south of Oxford the proportion of calcareous wares, particularly coarse shelly ware, tends to decline from the early Iron Age while the proportion of sandy wares with limestone tends to increase, progressing from the early to middle Iron Age. By contrast, in the north and east of the county calcareous wares tend to continue well into the middle Iron Age, for example, at Bicester (Marter and Brown 2011), Bloxham (Blinkhorn 2009) and Banbury (Biddulph 2004). This means that, where there are non-diagnostic well-fragmented groups of material, close dating can be quite difficult. The limited typological range seen here, with the predominance of barrel-shaped or globular jars, and the presence of saucepan-style vessels, would suggest that most of this assemblage dates to the middle Iron Age, which correlates with the radiocarbon dating. In terms of vessel typology, the assemblages from Area 2 and Area 7 find close parallels with other middle Iron Age material across the county typified by assemblages such as those from Watkins Farm, Northmoor (Allen 1990), Cassington (Harding 1972), Ashville (De Roche 1978), Farmoor (Lambrick and Robinson 1979) and Gravelly Guy (Lambrick and Allen 2004). The absence of fabrics typical of the later Iron Age would suggest the sites were abandoned during, or at the end of, the middle Iron Age.

\section{Catalogue of illustrated sherds (Figure 18)}

- P1. Wide-mouthed jar with a slightly concave inner face. Fabric: SHLI3. Dark grey in colour. Ditch [02112] (02111).

- P2. Plain-walled saucepan-style pot. Fabric: SA1. Black surfaces with a redbrown core. Ditch [02112] (02111).

- P3. Simple rim jar. Fabric: SH1. Dark grey in colour. Ditch [02112] (02111).

- P4. Simple rim jar oxidised in colour with a grey core. Fabric: SHLI3. Ditch [02112] (02111).

- P5. Large, rounded bowl with beaded rim, orange-brown in colour with a grey core. Fabric: SALI. Pit [02014] (02013).

- P6. Crudely made jar with a simple undifferentiated rim. Fabric: SHLI3. Ditch [02010] (02008). 
- P7. Small body sherd decorated with a single row of shallow impressed dots. Orientation uncertain. Fabric: SHLI1. Ditch [02010] (02109).

- P8. Small S-shaped bowl brown in colour with a black core. Fabric: SH1. Sooted exterior. Pit [02072] (02069).

- P9. Barrel-shaped jar with an undifferentiated rim. Sooted exterior. Fabric: SAFSH. Pit [02072] (02071).

- P10. Globular bodied jar with a simple slightly everted rim. Fabric: SHLI2. Pit/burial pit [02084] (02086).

- P11. Simple rim jar. Fabric: SH1. Pit [07026] (7027).

- P12. Flared rim vessel with a sooted exterior. Fabric: SH1. Ditch terminal [07041] (07040).

- P13. Saucepan-style vessel with a highly burnished exterior and less well burnished interior. Black in colour with a brown interior. Fabric: SAF. Pit [07068] (07066).

- P14. Simple rim globular jar, brown in colour. Fabric: SHLI1. Pit [07086] (07066).

- P15. Large everted rim storage jar. Brown in colour with an orange core. Fabric: SHLI2. Pit [07068] (07066).

\subsubsection{Roman}

Sixty-four sherds weighing $635 \mathrm{~g}$ date to the Roman period (Table 6). These are distributed across 14 contexts within Area 1, Area 4, Area 7, Area 10 and Area 13 (Table 4). There are just two small concentrations of material: a group of 18 sherds from Area 10 subsoil (10001) dates to the mid-late Roman period (2nd-4th century AD) while a second collection of 17 sherds came from the hollow [07030] and are probably of earlier Roman date. The remaining 29 sherds are widely dispersed and largely lack any diagnostic features.

Traded wares are limited to an extremely small crumb of samian probably from a South Gaulish vessel, one sherd of Dorset black burnished ware (DOR BB1) (Tomber and Dore 1998,127$)$ and two sherds of Midlands pink grog-tempered ware (PNK GT) (Tomber and Dore 1998, 210).

Grog-tempered wares (BWGR, GYGR, OXGR; GROR): generally quite soft fabrics with a smooth soapy or slightly sandy feel and sparse sub-rounded grog/clay pellets. A single grog-tempered sherd is also organic-tempered (GROR). Forms are limited to handmade storage jars in fabrics OXGR and GROR and jar body sherds. 
Table 6: Quantification of Roman pottery from across the pipeline.

See http://romanpotterystudy.org.uk/nrfrc/, the fabric reference collection

$\begin{array}{lllll}\text { Fabric code Description } & \text { No. No. } \% & \begin{array}{l}\text { Wt } \\ (\text { g) }\end{array}\end{array}$ Wt\% $\quad$ EVE EVE $\%$

\begin{tabular}{|c|c|c|c|c|c|c|c|c|}
\hline \multirow[t]{2}{*}{ Traded } & samian & & 1 & 1.56 & 0.25 & 0.04 & 0 & 0.00 \\
\hline & DOR BB1 & $\begin{array}{l}\text { Dorset black } \\
\text { burnished ware }\end{array}$ & 1 & 1.56 & 10 & 1.57 & 0 & 0.00 \\
\hline & PNK GT & $\begin{array}{l}\text { pink grog-tempered } \\
\text { ware }\end{array}$ & 2 & 3.13 & 51 & 8.03 & 0 & 0.00 \\
\hline \multirow[t]{4}{*}{ Grog } & BWGR & black grog-tempered & 2 & 3.13 & 25 & 3.94 & 0 & 0.00 \\
\hline & GROR & $\begin{array}{l}\text { grog and organic- } \\
\text { tempered }\end{array}$ & 1 & 1.56 & 27 & 4.25 & 0 & 0.00 \\
\hline & GYGR & grey grog-tempered & 10 & 15.63 & 83 & 13.07 & 0 & 0.00 \\
\hline & OXGR & $\begin{array}{l}\text { oxidised grog- } \\
\text { tempered }\end{array}$ & 4 & 6.25 & 177 & 27.87 & 0.11 & 22.45 \\
\hline \multirow[t]{5}{*}{ Local } & OXF RE & $\begin{array}{l}\text { Oxon grey sandy } \\
\text { ware }\end{array}$ & 5 & 7.81 & 22 & 3.46 & 0 & 0.00 \\
\hline & OXF FR & $\begin{array}{l}\text { Oxon fine grey sandy } \\
\text { ware }\end{array}$ & 3 & 4.69 & 50 & 7.87 & 0 & 0.00 \\
\hline & OXF RS & $\begin{array}{l}\text { Oxon red-slipped } \\
\text { ware }\end{array}$ & 1 & 1.56 & 12 & 1.89 & 0 & 0.00 \\
\hline & OXF RS(M) & $\begin{array}{l}\text { Oxon red-slip } \\
\text { mortaria }\end{array}$ & 2 & 3.13 & 7 & 1.10 & 0 & 0.00 \\
\hline & OXF WH & Oxon white ware & 1 & 1.56 & 5 & 0.79 & 0.01 & 2.04 \\
\hline \multirow[t]{7}{*}{ Misc. } & BWSY & black sandy ware & 19 & 29.69 & 121 & 19.06 & 0.15 & 30.61 \\
\hline & GY & grey sandy ware & 1 & 1.56 & 18 & 2.83 & 0.07 & 14.29 \\
\hline & OXID & oxidised sandy ware & 2 & 3.13 & 13 & 2.05 & 0 & 0.00 \\
\hline & OXIDFSY & $\begin{array}{l}\text { fine oxidised sandy } \\
\text { ware }\end{array}$ & 2 & 3.13 & 4 & 0.63 & 0 & 0.00 \\
\hline & OXIDF & fine oxidised ware & 6 & 9.38 & 9.25 & 1.46 & 0.15 & 30.61 \\
\hline & PALE & pale sandy ware & 1 & 1.56 & 0.5 & 0.08 & 0 & 0.00 \\
\hline & \multicolumn{2}{|l|}{$\mathrm{TC}$} & 64 & 100.00 & 635 & 100.00 & 0.49 & 100.00 \\
\hline
\end{tabular}


Oxfordshire wares (OXF RE, OXF FR, OXF RS and OXF WH) (Tomber and Dore 1998, 173). The only featured sherds are two pieces of red-slipped mortaria and a small fragment of possible flange from a whiteware mortarium.

Other Sandy wares: most of the individual groups are quite small but include a blacksandy ware (BWSY), grey or oxidised sandy ware (GY, OXID, OXIDFSY), a fine oxidised ware (OXIDF) and a small fragment of pale sandy ware (PALE). The only featured sherds are a flask in fine oxidised ware (OXIDF) and three handmade jars in black sandy ware (BWSY).

\subsubsection{Post-medieval}

A small assemblage of 50 sherds (308g) was recovered from Areas 7, 10-12, spanning the 16/17th-19th centuries. Fabrics include Westerwald stoneware, other German stoneware, English stoneware, glazed and unglazed red earthenware, Brill-Boarstall type glazed ware, Midlands Purple stoneware, salt-glaze ware and industrial glazed white ware.

\subsubsection{Discussion}

Of the 520 contexts recorded, 89 yielded pottery, so the overall density of activity as revealed by the pottery is low. Area 1 revealed a small collection of Roman CBM from field boundary ditches [01007] and [01019] accompanied by two sherds of early Roman grey grog-tempered ware from [01021]. Linear [01015] contained a single jar sherd of calcareous Iron Age pottery and five unidentifiable crumbs. Adjacent Area 13 over Akeman Street produced a sparse collection of material including a minute crumb of probably South Gaulish samian from (13021) - a layer on the road - which would most likely have come from a vessel of later 1 st or early 2 nd century date.

Most of the Iron Age pottery and fired clay was recovered from Area 2, with some 696 sherds of pottery (including crumbs) and 66 fragments of fired clay in total. Several good groups were recovered - in particular, from ditches [02010] and [02112] and pits [02045] and [02072] (Figure 7). The spectrum of wares suggests a middle Iron Age date for this activity.

Eight body-sherds of calcareous-tempered Iron Age pottery were recovered from Area 3 , distributed across two ditches [03023, 03065] and one pit [03003]. The fabric is one that also features in Area 2 so a similar date is inferred. Area 4 was equally poor in ceramic terms with just three sherds and two crumbs. Two early Roman pieces came from the colluvium and an Iron Age calcareous ware from ditch [04018].

No pottery was recovered from Area 5 and Area 6 but a concentration of 426 sherds (including crumbs) of Iron Age date came from Area 7, accompanied by 18 early Roman sherds and one post-medieval piece. The range of material is very similar to that from Area 2 intimating a broadly similar date of activity dating to the middle Iron Age. This area produced the only traded piece, a sherd from the Malvernian area, which could tentatively suggest the site is slightly later or of longer duration than Area 2. The fabrics are largely calcareous wares, with few featured sherds to allow much refinement of chronology. Most of the pottery came from various pits and ditches with the largest groups of material comprising 31 sherds from pit [07026] and 67 sherds from pit [07068]. 
Compared to $\underline{\text { Area } 2}$ far less fired clay was recovered from this zone, with just four fragments.

Area 9 produced nine shell and limestone-tempered body sherds, eight crumbs and three fragments of fired clay all from ditch [09009]. An Iron Age date is inferred. Slightly more finds came from Area 10 with 60 pieces including one possible Beaker sherd, 28 Roman sherds and 20 post-medieval. Post-hole [10004] is undated, containing just 11 small crumbs. A very small sherd, possibly Beaker, came from ditch [10024]. Most of the Roman sherds came from the colluvium (10001) with a date range extending into the later 3rd to 4th century. A single sherd of OXF WH came from ditch [10009] suggesting a mid- to later Roman date and nine sherds from ditches [10061], [10064] and [10070], which suggest a date in the earlier to mid-Roman period.

\subsection{Lithics by Julie Lochrie}

The lithics numbered 28 finds, scattered through topsoil, and several ditches and other features. These are prehistoric in date and largely appear to be residual. Finds include tools, some debitage and a single core. The only diagnostic elements in the assemblage are of Neolithic or early Bronze Age date, including a knife scraper with semi-abrupt retouch to all remaining edges (from ditch [2115] (2008)) and another tool with distinctive retouch (from topsoil 11000). The most interesting group are five finds from the top of a natural deposit in Area 12 (12002) including a multi-platform core, a possible piercer, a notched flake and debitage.

\subsection{Fired clay and ceramic building material by Jane Timby}

Some 66 pieces of fired clay were recorded weighing $609.5 \mathrm{~g}$, most of which was associated with the middle Iron Age pottery. Most pieces are in fine textured clay with no features to identify an original purpose. None of the pieces appear to have been subjected to high temperatures as might be associated with kilns, ovens or furnaces. Most of the pieces, $85 \%$, came from Area 2 with just a few pieces from Area 7 and Area 9. Twenty-six fragments of CBM were recovered weighing $1396 \mathrm{~g}$. At least 19 pieces, 1294g, are likely to be Roman in date and these all came from two ditches: [01007] and [01019] in Area 1. The fragments include roofing tile (tegulae), flat tile and a single piece of a combed box-flue that is sooted from use. The remaining pieces are from the unstratified collection and furrow [10031] and, with one possible exception of an abraded Roman fragment, are probably all post-Roman in date.

\subsection{Glass bead by Julie Lochrie}

A glass bead (Guido Class 5, Hanging Langford type (Guido 1978)) was found in the disturbed burial [02084]. The shape and colour of the bead is unusual (Figure 19). It is large $(29 \mathrm{~mm}$ dia; $11 \mathrm{~g})$ and of slightly irregular annular form, with decoration that makes it appear to glow from within. This has been achieved by the application of an opaque yellow trail inside the hourglass perforation of a plain, clear glass bead. Beads of this size are large enough to have been used in ways other than strung jewellery and could have been used as hair ornaments or hung from torcs. Wear on the bead suggests that 
it has been threaded through something, causing wear to both edges on one side and a polish to either face.
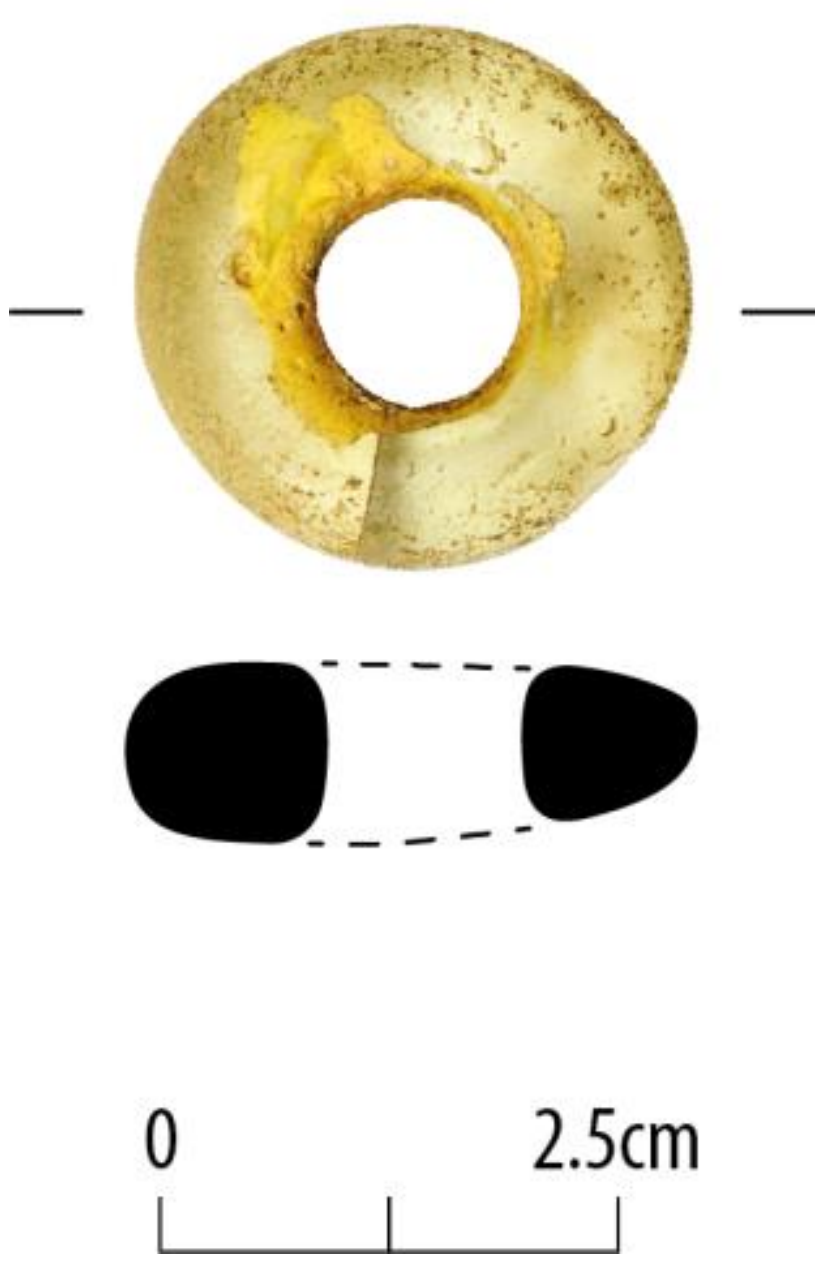

Figure 19: Glass bead from burial [02084]

\subsection{Industrial waste by Julie Franklin}

A small collection $(189 \mathrm{~g})$ of industrial waste was recovered including a few lumps of iron slag and some magnetic residues retrieved from sample retents. The latter include fragments of magnetised gravel and some possible hammerscale fragments. The largest collection (131g) was found in pit [02084] associated with the two burials and a quantity of apparent domestic waste. Most of the other remains were also found in Iron Age features and suggest iron smithing on or near the site during that period.

\subsection{Metalwork by Holly B. Duncan}

A total of 58 items of metalwork was recovered from four areas, comprising 53 iron and 5 copper-alloy objects. The assemblage survived in fragmentary condition with few complete objects; 12 metalwork items could only be identified as fragments of sheet, bar/shank or wire. 


\subsubsection{Copper alloy}

Five copper-alloy items were recovered, all from Iron Age deposits. A 6.4mm length of gently tapering circular sectioned wire $(1.5 \mathrm{~mm}$ diameter) was found within the fill of pit [02004]. This could have served as a small rivet or perhaps part of a brooch pin. Three tiny fragments of sheet, thicknesses ranging from $0.5 \mathrm{~mm}$ to $1.5 \mathrm{~mm}$ and length not exceeding 3mm, were found in the fills of ditch [07057] (1 piece) and quarry pit [07068] (2 pieces); the diminutive size of these fragments precludes certainty as to original form. A portion of circular-sectioned wire $(1 \mathrm{~mm}$ diameter) bent into a penannular shape, forming a ring or coil measuring $6 \mathrm{~mm}$ by $5 \mathrm{~mm}$, was found within the fill of burial [02084] and could have been associated with the burial, rather than the later domestic waste. The presence of copper-alloy staining on the right side of the atlas vertebra and the upper end of the right humerus of the remains of the child hints at further copper-alloy objects that may have been robbed.

\subsubsection{Iron}

The ferrous assemblage comprises mainly fragmentary, undiagnostic items and the occasional nail. Romano-British deposits in the fill of pit [07034] and the fill of post-hole [10004] did produce evidence of footwear in the form of hobnails. While only one hobnail was recovered from pit [07034], presumably representing accidental loss during use, post-hole [10004] contained at least 39 hobnails (39 heads and 22 portions of shank) and up to three flat-headed nails/tacks. It is not possible to determine if the deposit in post-hole [10004] represents a single heavily nailed shoe or perhaps a pair of lightly nailed shoes. Accompanying the hobnails in the charcoal-rich post-hole fill were frequent inclusions of ceramic building material, iron slag and burnt animal bone.

\section{Environmental Evidence}

\subsection{Plant remains by Angela Walker}

A total of 39 samples, ranging in size from five to forty litres, were recovered during the excavation. The overall assemblage of recorded plant remains was low and these were poorly preserved. Wheat (glume wheat and free-threshing wheat) and barley were present across all feature types and in the majority of excavation areas. The presence of cereal grain, chaff and charcoal fragments in the charred plant assemblage suggests the disposal of domestic rubbish generated via conflagration activities (e.g. cooking).

\subsection{Faunal remains by Veronica Anicetti, Mauro Rizzetto and David Henderson}

A small assemblage of faunal remains - 169 NISP (number of identified species) - was subject to full analysis from the excavations, mostly from middle Iron Age contexts in Area 2 and Area 7 (Table 7). 
Table 7: Number of identified animal specimens (NISP) from hand-collected and sieved faunal material by period

\begin{tabular}{|c|c|c|c|}
\hline Animal taxon & Iron Age & $\begin{array}{c}\text { Romano- } \\
\text { British }\end{array}$ \\
\hline Cattle (Bos taurus) & Hand-collected & Sieved & Hand-collected \\
\hline Caprines (Ovis/Capra) & 39 & 3 & 3 \\
\hline Pig (Sus sp.) & 50 & 26 & 1 \\
\hline Equids (Equus sp.) & 12 & 1 & 1 \\
\hline Dog (Canis familiaris) & 8 & 0 & 0 \\
\hline Galliform (Gallus/Numida/Phasianus) & 3 & 0 & 1 \\
\hline Badger (Meles meles) & 0 & 1 & 1 \\
\hline Large rodent (Rattus/Arvicola) & 1 & 0 & 0 \\
\hline Small rodent (small Murinae; small Microtinae) & 0 & 3 & 0 \\
\hline Passeriformes & 0 & 12 & 0 \\
\hline Amphibians (Rana/Bufo) & 113 & 49 & 0 \\
\hline Total & 0 & 2 & 0 \\
\hline
\end{tabular}

Sheep and goats (Ovis aries/Capra hircus) are the most represented species (50\%), followed by cattle (Bos taurus, 39\%) and pig (Sus sp., 12\%) (Table 7). Based on morphological criteria no goats were identified, while nine fragments could be assigned to sheep (Ovis aries). Among domestic species, Equidae (probably horse, Equus caballus) are also present (eight fragments), along with three bones of dog (Canis familiaris). Wild species are only represented by the pelvis of a badger (Meles meles).

There is a higher incidence of cattle butchered bones in comparison to goats and sheep. This is typical, resulting from the fact that the larger carcasses of cattle require more extensive butchery to be separated into smaller portions for distribution. Goats and sheep played an important role in husbandry practices, and were culled for different purposes, suggesting the existence of a generalised economy, typical of this period (Hambleton 1999). The cattle and sheep bones derive from animals of all ages, from newly born to perhaps over eight years. Generally, the material from Areas 3, 4 and 7 is from older cattle and sheep, probably stock kept for dairy, wool and traction, while there is a higher proportion of younger animals in Area 2, perhaps indicating that this area was receiving animals culled for meat once they had attained full size. Among the faunal assemblage were several bones showing evidence of canid gnawing, owing to dogs scavenging. 
Of note was the concentration of bones of young lambs in the fill of the burial [02084]. It is possible that these animals derived from funerary deposits associated with the burials. Cat bones deriving from two different animals were also recovered from the pit; it is possible that these were attached to pelts, perhaps used as trimming for a garment. Other animal bones in the pit, however, show extensive butchery and dog-chewing, suggesting that general refuse was also incorporated into the backfill of the pit after disturbance of the human remains.

\subsection{Human remains by Sue McGalliard}

Both individuals in pit [02084] had been extensively disturbed, with unarticulated adult bones (SK2107) scattered throughout the fill. These overlay the partial skeleton of a child (SK2108) which was aligned north to south and appeared to be lying on its right side with the left arm flexed towards the chest (Figure 9 ). As the individuals were placed within the same grave cut and were surrounded by the same fill, it is probable that they were interred together and therefore likely to be family members or part of the same group. Both skeletons were of moderate condition, with some intact long bones and recovery of the small bones in the hands and feet. Despite some degree of weathering, the bone surface was relatively good. Dentition was also recovered from both skeletons and was in good condition.

Skeleton SK2107 was identified as an adult male between 40 and 44 years old at the time of death. Based on the maximum length of the femur, living stature was estimated at $158.75 \mathrm{~cm} \pm 3.27$ or $5 \mathrm{ft} 2.5 \mathrm{in}$. The skeleton had bilateral squatting facets on the anterior of the distal tibiae. Squatting facets are common in ancient populations and caused by habitual dorsiflexion of the ankle joints, which occur when a person is in the squatting position (Mays 2010). The skeleton also exhibited some evidence of osteoarthritis in the form of osteophytes on the margins of the third and fourth lumbar vertebrae and at the left and right proximal tibia-fibular joint. Slight periostitis was observed on the left and right medial midshafts of the tibia, potentially caused by an injury to the inner thigh. Very slight trauma was also observed in the form of an ossified haematoma on the lateral midshaft of the left femur, which was caused by a muscle injury. Additionally, developed muscle attachments were also visible at the knee and ankle joints, suggesting repetitive and prolonged activity that caused the muscles to develop and become strained occasionally. This is also consistent with the periostitis discussed above. Skeleton SK2108 was identified as a child of about 12 years old. It had supra-orbital notches on the left and right side, which is a common trait in many populations.

The dentition of both skeletons was generally in good condition and measurable. Both individuals had worn the occlusal enamel surfaces to the extent that the underlying dentine was exposed. Both also exhibited slight calculus on some teeth. Skeleton SK2107 had a large mesial caries on the upper left and right second molars. SK2108 had a large mesial caries on the upper right first molar and on the distal side of the upper left first molar. SK2108 also had enamel hypoplasia, indicating a period of ill health in early childhood that was severe enough to interrupt the development of the dentition (Waldron 2009). 


\subsection{Soil micromorphology by Richard Macphail}

Table 8: Location and summary of micromorphology samples (for context location see Figure 6)

Sample number

M5

M6

M7
Context

$13001 / 13021$

$13002 / 13014$

$13002 / 13014$
Description

roadside silts

local decalcified soil - trample/traffic

local decalcified soil - trample/traffic

Three thin-section samples were taken from Area 13 - two from soil buried beneath the Roman road and one from an example of the roadside silts (Table 8) (Figure 6). The samples were assessed and studied according to established soil micromorphology methods. The Roman road buried soil is a rare, preserved example of decalcified soil formed on Jurassic Limestone in an area of modern calcareous soils that are the result of arable agriculture. The buried soil has no natural structural traits and instead is totally homogenised and characterised by matrix intercalations, closed vughs and embedded grains. It can be suggested that it has been transformed by continuous wet churning caused by probable passage of people, animals and wheeled transport (Macphail and Goldberg 2017; Rentzel et al 2017). The presence of small concentrations of iron phosphate $(0.22-0.31 \% \mathrm{P} ; 11.8-15.2 \% \mathrm{Fe})$ and trace amounts of fungal material can also be typical of such trackways. A muddy trackway thus seems to pre-date the constructed Roman road in this location. Other examples of Iron Age trackways underlying Roman roads come from Ware, Hertfordshire, and Sharpstone Hill, Shropshire, which also show such homogenised deposits (Macphail and Crowther 2013; Malim and Hayes 2011).

The roadside 'silts' are composed of finely mixed decalcified soil and calcareous sands and gravels and have presumably accumulated through erosion of the metalled road surface as a localised calcareous colluvium. Both the buried trackway and Roman road 'silts', despite recording traffic, have a not unexpected 'rural' road signature compared to urban roads. The full soil micromorphology report is available in the site archive. 


\section{Discussion}

Despite comprising a relatively narrow slice through the landscape, the results from the excavations along the Angelinos pipeline add to our growing knowledge of the wider area. This landscape has seen relatively limited earlier investigation in comparison with the gravel terraces of the Thames Valley to the south, which have, owing to the impact of gravel extraction from the 1970s, tended to dominate archaeological research in the region. Most of the previous excavations, not including the various antiquarian investigations, have taken place in advance of commercial developments revealing elements of an Iron Age and Roman landscape, including the presence of linear Iron Age settlements, and zones of Roman settlement near Banbury and especially around Bicester (Figure 2). Excavations along the Angelinos pipeline have therefore afforded the opportunity to examine a slice through this north Oxfordshire landscape, facilitating the examination of a number of sites. These ranged from sites with evidence of occupation activities to the remains of field systems and boundary ditches (Table 9).

As with all linear schemes this approach came with its own limitations. Notably this included the inability to examine the full extent of recorded settlement remains, as in Area 2 and Area 7, which as shown by the geophysics form part of larger settlements and/or landscapes. This is also true of the various field boundaries recorded across the scheme, which were in many cases accompanied by banks. Despite these limitations the results of the excavation present an important addition to the overall corpus of known sites from this region, aiding in refining our overall understanding of the use of the landscape from prehistory into the post-medieval period.

In the following discussion the archaeology from the pipeline is summarised by period, drawing together key themes, including the role and development of enclosures over time and the evidence for domestic and funerary activity within the excavated areas. These themes derive from the original aims set out at the beginning of this publication. 
Table 9: Summary of principal features and possible site functions

\begin{tabular}{|c|c|c|c|c|}
\hline Area & Features & Primary date & Site function & Other activities \\
\hline $1 / 13$ & $\begin{array}{c}\text { Akeman Street, } \\
\text { trackway }\end{array}$ & Roman & Transport & $\begin{array}{l}\text { Drainage } \\
\text { ditches/field } \\
\text { boundaries }\end{array}$ \\
\hline 2 & $\begin{array}{l}\text { Field boundaries, } \\
\text { enclosures, pits }\end{array}$ & $\begin{array}{l}\text { Middle Iron } \\
\text { Age }\end{array}$ & $\begin{array}{c}\text { Occupation activities, } \\
\text { livestock rearing and } \\
\text { butchery }\end{array}$ & $\begin{array}{l}\text { Possible evidence } \\
\text { for smithing }\end{array}$ \\
\hline 3 & $\begin{array}{l}\text { Boundary ditch, } \\
\text { Structure } 1\end{array}$ & $\begin{array}{l}\text { Middle Iron } \\
\text { Age }\end{array}$ & $\begin{array}{l}\text { Possible occupation } \\
\text { site - ?field system }\end{array}$ & \\
\hline 4 & $\begin{array}{c}\text { Possible } \\
\text { enclosure/boundary } \\
\text { ditch }\end{array}$ & $\begin{array}{l}\text { Middle Iron } \\
\text { Age }\end{array}$ & ?Stock management & Traces of iron slag \\
\hline 5 & $\begin{array}{l}\text { Undated pits and } \\
\text { ditches }\end{array}$ & Undated & Uncertain & \\
\hline 7 & $\begin{array}{l}\text { Field boundaries, } \\
\text { enclosures, pits }\end{array}$ & $\begin{array}{l}\text { Middle Iron } \\
\text { Age }\end{array}$ & $\begin{array}{l}\text { Possible occupation } \\
\text { site - ?field system }\end{array}$ & \\
\hline \multirow[t]{2}{*}{9} & $\begin{array}{l}\text { Enclosure boundary } \\
\text { ditch }\end{array}$ & $\begin{array}{l}\text { Middle Iron } \\
\text { Age }\end{array}$ & $\begin{array}{l}\text { ?Field system or stock } \\
\text { management }\end{array}$ & \\
\hline & Ditches/post-holes & ?Iron Age & Indeterminate & \\
\hline
\end{tabular}

Disturbed

midden/manure spreading; possible ritual deposition?

10

Colluvium/ditches Post-hole

Roman

Ploughing/agricultural activities 


\subsection{Chalcolithic/early Bronze Age}

Pre-Iron Age features were rare and confined to the finds of Beaker pottery from Area 10 and Area 12, dated to the Chalcolithic/early Bronze Age. The lithic finds from Areas 12,2 and 11 hint at further early prehistoric activity within the development. Given the heavily abraded nature of the Beaker sherds it is possible that these are residual.

Beaker pottery is well documented within the wider Upper Thames Valley (Leeds 1938; Case 1956; Clarke 1970). Most of the recorded Beaker pottery from within the region derives from funerary contexts, although there has over the last few decades been a notable increase in the recorded number of examples from domestic contexts (see Morigi et al. 2011, 315-17 for an overview). Excavations at Yarnton uncovered a large assemblage of Beaker pottery deriving from both funerary and domestic contexts (Hey et al. 2016), while several Beakers were recorded at Gravelly Guy (Lambrick and Allen 2004) (Figure 2).

\subsection{Middle Iron Age}

Most of the archaeology recorded from within the development corridor was dated to the middle Iron Age, centred on Areas 2-4, 7, 9 and possibly 10 (Table 9). There was no evidence for early or later Iron Age activity, but this could lie outside the excavation limits. Early and later Iron Age archaeology is reasonably well attested within the wider vicinity of the development area, including the late Iron Age enclosure at Bicester Fields Farm, which was occupied into the early 1st century AD (Cromarty et al. 1999), and the early Iron Age activity at Heyford Road (Cook and Hayden 2000) (Figure 2; Table 10).

Detailed phasing of the features from across the pipeline was not possible, considering the limited range of datable material and stratigraphic relationships. Radiocarbon dating of material from pits in Area 2 suggests that the site was occupied between the mid-4th to 2 nd century BC, while pits in Area 7 were broadly dated to the late 5th to 3rd century $\mathrm{BC}$ (Figure 3 ). It is possible that both sites were contemporary with each other. The range of dates closely overlaps with other known Iron Age sites in the region, including Bicester Fields Farm, dated to the later part of the middle Iron Age with activity extending into the mid-1st century AD (see Table 10). Both Area 2 and Area $\underline{7}$ comprised small 'unenclosed' settlements associated with a focus on the management of livestock. The nature of occupation in Area 3 is unclear, comprising a single post-built structure (Structure 1), which could have been truncated by a later boundary ditch (Figure 10). The remaining middle Iron Age features from Area 4 and Area 9 comprised substantial boundary ditches, in some cases associated with banks (Table 9). Dating evidence for these was extremely limited and their assignment to the middle Iron Age is provisional. These ditches could represent the remains of coaxial field systems or have defined areas of pasture. 


\subsubsection{Settlement layout}

Table 10: Examples of Iron Age settlement sites near to the development

\begin{tabular}{|c|c|c|c|c|c|}
\hline $\begin{array}{l}\text { Site } \\
\text { name }\end{array}$ & HER & Date & $\begin{array}{l}\text { Type (unenc. } \\
\text { or enclosed) }\end{array}$ & $\begin{array}{l}\text { Primary } \\
\text { features }\end{array}$ & Notes \\
\hline $\begin{array}{l}\text { Heyford } \\
\text { Road }\end{array}$ & 16024 & $\begin{array}{l}\text { Early Iron } \\
\text { Age }\end{array}$ & Indeterminate & $\begin{array}{l}\text { Pit groups/pit } \\
\text { alignment } \\
\text { Boundary } \\
\text { ditches }\end{array}$ & $\begin{array}{c}\text { Multiple phases of } \\
\text { activity - possible } \\
\text { discontinuity between } \\
\text { middle and later Iron } \\
\text { Age } \\
\text { Roman phase of activity }\end{array}$ \\
\hline $\begin{array}{l}\text { Duns } \\
\text { Tew }\end{array}$ & 28739 & $\begin{array}{c}2 \text { nd-1st } \\
\text { century } \\
\text { BC }\end{array}$ & $\begin{array}{l}\text { Enclosed - } \\
\quad \text { linear } \\
\text { settlement }\end{array}$ & $\begin{array}{c}\text { Domestic and } \\
\text { stock enclosures } \\
\text { Sub-enclosures } \\
\text { Roundhouses - } \\
\text { ring ditches }\end{array}$ & $\begin{array}{l}\text { Enclosures connected } \\
\text { by ditch }\end{array}$ \\
\hline \multirow[t]{2}{*}{$\begin{array}{l}\text { APST } \\
\text { Pipeline }\end{array}$} & & $\begin{array}{l}\text { 4th-early } \\
\text { 2nd } \\
\text { century }\end{array}$ & Enclosed & $\begin{array}{l}\text { ?Banjo } \\
\text { enclosure }\end{array}$ & \multirow[t]{2}{*}{$\begin{array}{c}\text { Four burials of } \\
\text { infants/young children }\end{array}$} \\
\hline & & $B C$ & Unenclosed & & \\
\hline \multirow[t]{2}{*}{$\begin{array}{l}\text { Slade } \\
\text { Farm }\end{array}$} & \multirow[t]{2}{*}{15867} & MIA-LIA & Unenclosed & $\begin{array}{l}\text { Linear boundary } \\
\text { Ring gullies and } \\
\text { pits }\end{array}$ & \\
\hline & & $\begin{array}{l}\text { Late Iron } \\
\text { Age }\end{array}$ & & $\begin{array}{l}\text { Linear boundary } \\
\text { Pottery kiln }\end{array}$ & \\
\hline $\begin{array}{l}\text { Bicester } \\
\text { Fields } \\
\text { Farm }\end{array}$ & 16120 & $\begin{array}{l}\text { MIA- mid- } \\
1 \text { st } \\
\text { century } \\
\text { AD }\end{array}$ & Enclosed & $\begin{array}{l}\text { Settlement } \\
\text { enclosure } \\
\text { Roundhouse } \\
\text { Associated } \\
\text { droveways and } \\
\text { ditches } \\
\text { Waterhole }\end{array}$ & $\begin{array}{l}\text { Economy of site largely } \\
\text { pastoral focused on beef } \\
\text { production } \\
\text { Limited evidence for iron } \\
\text { working }\end{array}$ \\
\hline
\end{tabular}

Domestic activity in Area 2 and Area 7 were focused on a series of ditches and pit clusters, the majority of which contained quantities of domestic debris, suggesting fairly intensive episodes of occupation. In Area 2 this included probable evidence of smithing, although this in itself is not unusual (Table 9). Evidence of smithing has been found at most extensively examined Iron Age settlements in the wider region (Lambrick and Robinson 2009, 218; see also Salter and Ehrenreich $\underline{1984}$ for an overview). In Area $\underline{7}$ the remains of a number of curvilinear ditches were recorded, which could represent small enclosures, possibly defining small stockyards or enclosures. The curvilinear ditch [07064] was cut by a series of pits containing quantities of domestic debris, which formed the primary category of evidence for the site. Pits are a recurrent feature at Iron 
Age sites in the Upper Thames Valley; at Gravelly Guy around 915 pits were recorded within the main excavation area, forming a major element of the settlement (Lambrick and Allen 2004, 106). Most of the recorded pits at Gravelly Guy were more or less circular in plan, varying from 0.3 to $2.5 \mathrm{~m}$ diameter and from $0.05 \mathrm{~m}$ to $1.65 \mathrm{~m}$ in depth (Lambrick and Allen 2004, 109). In contrast, most of the pits from the Angelinos Pipeline excavations were fairly shallow, suggesting either greater levels of truncation or an alternative function for these. Alongside these were several cylindrical or straight-sided pits, which could have functioned as storage pits.

The form and layout of the probable settlements in Area 2 and Area 7 is typical of the Iron Age in the Upper Thames Valley and surrounding areas. Settlement types during this period can be broadly divided into enclosed and unenclosed types. Unenclosed settlements with paddocks are widely recorded across the Thames Valley (Lambrick 1992, 93-97). These include the well-documented sites at Claydon Pike (Miles et al. 2007) c. $36 \mathrm{~km}$ to the south-west of the pipeline and Thornhill Farm c. $5 \mathrm{~km}$ to the north-west of Claydon Pike (Jennings et al. 2004). Closer to the pipeline, middle Iron Age settlements have been recorded at Heyford Road (Cook and Hayden 2000), Duns Tew (Hewitt 2016) and Bicester Fields Farm (Cromarty et al. 1999) and comprise a mix of enclosed and unenclosed settlements (Table 10) (Figure 2). During excavations in advance of the Thames Water mains reinforcement between Kirtlington and Ardley, two enclosed settlements were recorded with a third unenclosed settlement nearby. The latter comprised a large boundary ditch with a series of pits to the west, recalling the form of settlement recorded in Area 2 and Area 7 (Hart et al. 2010).

Structure 1 in Area 3 is typical of the period, with the rest of the structure probably being formed from perishable materials such as cob or mass-walling. The house could have accommodated an extended family, although given the absence of hearths and other features it is also possible that it represents a non-domestic structure, perhaps used on a seasonal basis. The association of Structure 1 with a ditch recalls that at Slade Farm, especially Area $\mathrm{C}$, where a linear boundary was cut by a ring gully with an internal diameter of $10 \mathrm{~m}$ (Ellis et al. 2000, 218). Iron Age structures across the region include post-built examples and post-built examples with ring gullies. Some structures are known only through the presence of drip-gullies (Allen et al. 1984; see also Lambrick and Robinson 2009, 133-42). At Slade Farm two roundhouses defined by ring-gullies were recorded, while Structure 1 at Bicester Fields Farm was defined by a substantial ditch, interpreted as a large enclosure (Ellis et al. 2000).

\subsubsection{Land boundaries}

A wide array of ditches was recorded across the pipeline, falling into two broad categories; enclosure ditches and field or territorial boundaries. The latter, as in Area $\underline{3}$ and Area 4 , were often substantial, up to $3.2 \mathrm{~m}$ wide and $0.80 \mathrm{~m}$ deep, and were frequently associated with banks, enhancing the scale and presence of these features. Evidence of recuts suggests regular maintenance, as was noted in several ditches within Area 2. As shown by geophysical survey to the east of Area 4, these ditches appear to form part of larger linear features extending across the landscape (Figure 11). Similar land divisions are widely recorded across the region (see Lambrick and Robinson 2009, chap. 3 for an overview), including the example at Duns Tew, associated with a settlement dated to the 2nd and 1st centuries BC (Hewitt 2016) and a major boundary ditch recorded at Slade Farm, which was recut on multiple occasions (Ellis et al. 2000, 260). A substantial middle Iron Age ditch was recorded north-east of 
Cassington and was traced for $305 \mathrm{~m}$ in a roughly north-west to south-east line. OSL dating showed the ditch was middle Iron Age in date and had been recut 379-110 cal BC (95\% probability) (Hey et al. 2011, 282).

The presence of these ditches reflects a concern with demarcating aspects of the landscape. As seen at Aves Ditch and Grims Ditch, these boundaries could reach monumental proportions, acting as clear markers in the landscape, potentially serving as 'tribal' divisions (Lambrick and Robinson 2009, 368-70). In the case of the boundary ditches recorded within the corridor, these may have served to demarcate various fields and areas of pasture, though the substantial nature of some of them could suggest more significant territorial boundaries. As seen at Area 4, these boundaries could be associated with other features including small enclosures, probably representing small stockyards. Alternatively, as at Area 2 and Area 3, these were associated with probable occupation zones. These boundary ditches could perhaps serve to demarcate territories belonging to kin groups, reflecting the development of systems of tenure and land-use rights in the Bronze and Iron Ages (Johnston 2001; 2005; Lambrick and Robinson 2009, 382).

\subsubsection{Settlement and economy}

The evidence from Area 2 and Area 7 points towards both sites representing the remains of fairly modest farmsteads, largely focused on pastoral regimes, with limited evidence for crop growing. There was a low incidence of cereals in the environmental remains, although preservation of cereal grains overall was poor. Evidence for storage pits or granaries was also not recorded at any of the sites, except perhaps for the bellshaped pit from Area 2. Instead, the economy of the sites may have been focused on the rearing of cattle and ovicaprids, the staple animals of the Iron Age (Hambleton 1999; Cunliffe 2005, 415-18). Sheep generally form the highest proportion of the main domesticates during the Iron Age (Albarella 2007; Serjeantson 2007), although there are local and regional variations. There were few incidences of wild species, suggesting a focus on the exploitation of domesticates. The occurrence of red deer antler appears to derive from the collection of shed antlers rather than from hunting. The presence of the dog remains may indicate that domestic species were used to aid in herding animals (Mulville 2008, 230; see also Pryor 2006).

Across the faunal assemblage there was clearly evidence for butchery, with all parts of the skeleton represented, suggesting the raising and slaughtering of animals on site. Evidence of skinning marks and horncores suggest a range of activities. It is possible that the shallow pits recorded within Area 2 could be related to these (e.g. waste pits, tanning, dyeing or scouring pits). In the case of the waste pits, it is possible that waste was initially collected in middens, being exposed to scavengers (such as dogs), before being deposited into pits (Needham and Spence 1996). The denser parts of the skeleton are most represented, perhaps indicating that differential survival in the pre- and postburial environment contributed to the make-up of the assemblage. Alternatively, 'meatier' higher value parts of the carcass tend to have less dense underlying bones, so it may be that the pattern of recovery reflects joints of meat being consumed elsewhere, away from the area of the excavations.

This focus suggests a degree of economic specialisation at the site with a largely pastoral economy centred on the exploitation of primary and secondary animal products. Generally, the material from Areas 3, 4 and 7 is from older cattle and sheep, probably 
stock kept for dairy, wool and traction, while there is a higher proportion of younger animals in Area 2, perhaps indicating that this area was receiving animals culled for meat once they had attained full size. This evidence, albeit limited, could reflect the existence of different areas of activity in the landscape being used for specific husbandry practices (e.g. grazing, lambing, over-wintering). The various field boundaries and enclosures could reflect further areas used for the management of livestock related to seasonal activities (Pryor 2006).

Other animals represented include the red deer antler from Area 2, which may have been collected with the intention of working it into objects. Two pieces of worked antler were recorded at Heyford Road, including an antler comb, which may have been used in weaving (Cook and Hayden 2000). Sheep dominated the faunal assemblage at Heyford Road, making up 59\% of the identifiable fragments. As at Angelinos, there was a high incidence of young sheep being slaughtered (Cook and Hayden 2000, 196). Wilson, in his analysis of the animal remains from Mingies Ditch, Oxon, suggested that the majority of immature animals killed were young rams or wethers (Wilson and Bramwell 1993, 190). The flock would then be maintained through a small number of rams or wethers (Wilson and Bramwell 1993). At Bicester Fields Farm there was a similar low incidence of cereal grains, with a focus on beef production (Cromarty et al. 1999) (Table 9). Other sites, such as the enclosures recorded near Kirtlington, show evidence for a more mixed economy (Wilson and Bramwell 1993).

\subsubsection{Funerary activity}

One of the more significant finds from Area 2 is the disturbed remains of a child and adult male, the latter dated to the middle-late Iron Age through radiocarbon dates of 34845 cal BC (SUERC-78746) and 369-176 cal BC (SUERC-78738) (Table 3; Figure 3). Human remains have been recovered in many Iron Age settlements in the Upper Thames Valley (Lambrick and Robinson 2009, 313), contrasting somewhat with the general paucity of Iron Age burials in other regions (Cunliffe 2005, see also Booth and Madgwick 2016). Past explanations of this apparent paucity have typically invoked excarnation as an explanatory factor (e.g. Cunliffe 2005, 543-61; Whimster 1977; 1981). Where burials are recorded in the Thames Valley these typically take the form of pit burials (Fitzpatrick 1997) and can range from single burials to larger clusters, as at Gravelly Guy where around 40 inhumation burials, spanning the Iron Age into the early Roman period were recorded (Hey et al. 2011, 180-88). At Yarnton, 35 inhumation burials in shallow pits were recorded, with radiocarbon dating of the remains suggesting that burials started around 420-230 cal BC and lasted till 290-150 cal BC (Hey et al. 2011). While rare, other Iron Age cemeteries are known within the wider region including Owlesbury in Hampshire (Collis 1994; see Lambrick and Robinson 2009, 3036). Single burials in pits occur at Heyford Road, where the remains of a young woman were recorded (Cromarty et al. 1999, 177). Double burials are also occasionally recorded from across the region, although in contrast to burial [02084] these typically consist of women and children (Lambrick and Robinson 2009, 323).

Wait (1985, 83-121, 233-45), using ethnographic parallels, suggested that people buried within Iron Age settlements were either liminal people (e.g. young or very old) or outcasts, ostracised either as social or religious minorities or because of an infraction of social or religious norms. Caution though should be expressed in applying blanket explanations to what is a clearly a highly varied (both spatially and temporally) practice that reflects a broad range of factors (see also Lambrick and Allen 2004, 248-9). Burial 
[02084] appears inconsistent with this model and is perhaps instead representative of individuals ascribed a particular status. The presence of grave goods, while not uncommon (see Lambrick and Robinson 2009, 20), reinforces this general impression. The bodies may also have been wrapped or covered with animal pelts, as indicated by the cats' paws, which may have served as trimming for a garment. The inclusion of lamb bones further hints at potential symbolic components to the burial. As indicated by the later disturbance, burial [02084] may have been marked out in some way, although this could have comprised a simple marker or low cairn.

Alongside this formal burial, possible disarticulated human remains were recorded from pit [02045]. The presence of such disarticulated human remains finds parallel with sites such as Heyford Road, where disarticulated human remains were also recorded from pits (Cook and Hayden $\underline{2000}, 193)$. The presence of infant/neonate remains in ditch fills is not unusual and has been noted at many other sites (Whimster 1981). This practice has often been interpreted as indicating casual treatment of the dead (Cunliffe $\underline{2005}$, 552; Whimster 1977, 318). More recent studies, though, have highlighted the potentially structured and symbolic significance of these deposits (e.g. Millett and Gowland 2015).

\subsection{Roman}

The relative paucity of late Iron Age activity in the pipeline corridor continues into the Roman period, with remains largely confined to Areas 1 and 13, where parts of a trackway and a section through Akeman Street were recorded. Evidence for Roman activity in the other areas was extremely limited, often confined to stray sherds of Roman pottery. In Area 10 the traces of a possible midden spread were recorded, from which the bulk of the Roman pottery assemblage was recorded. This could suggest the presence of Roman activity within the immediate vicinity, though this could also have accumulated through manure scatters. The number of hobnails recovered from a posthole at this site, indicating at least one and possibly two complete shoes, does, however, suggest that this landscape was actively managed during the Roman period. It remains uncertain if this footware was deliberately placed in this feature as part of some kind of ritual observance, though shoes (often recognised from hobnails) were recorded in c 5\% of Roman 'structured deposits' from 516 sites in a recent study (Smith et al. 2018, 189).

Detailed dating of the Roman activity is hampered by the pottery generally comprising sherds of undiagnostic regional wares, except for the Oxfordshire wares recorded from Area 10 dating to the 3rd to 4th century AD. The crumb of South Gaulish samian from Area 13 suggests a later 1 st or early 2 nd century date, although given the very small size of the sherd, and lack of other datable material, this cannot be used to provide a date for the construction of Akeman Street.

The limited Roman remains within the pipeline corridor lie within a wider landscape which, when considering both antiquarian finds and more recent excavations, appears to have been intensively occupied and farmed, comprising a network of small farmsteads, probable villa sites and small towns or roadside settlements (see also Smith et al. 2016 for an overview). These were connected by a series of trackways and more formal roads, including the key arterial road of Akeman Street.

\subsubsection{The development of Akeman Street and wider impact and changes in the landscape}


Although more constrained, the Roman evidence is centred upon the section excavated through Akeman Street in Area 13, providing further information about the development of the road. Akeman Street formed the primary routeway linking Verulamium, north-east of London, first to Alchester and then to Cirencester, passing through the earlier Iron Age boundary ditch, Grims Ditch. The samples of material taken for soil micromorphology from underneath the foundation layers of the road in Area 13 revealed deposits of 'dirty' natural (i.e. churned and mixed up by heavy animal traffic), which may be representative of an earlier Iron Age trackway. The case for such a route, linking oppida at St Albans and Bagendon, has been outlined by Copeland (2009), while recent excavations of a $150 \mathrm{~m}$ section of the road just to the east at Graven Hill also revealed layers of 'dirty natural' underneath the redeposited clay and limestone rubble and gravel of the road make-up (Allen et al. 2020, 11). However, other explanations for the evidence might also be considered. For example, the bioturbation could have occurred from the early phases of construction of the Roman road itself. Roadbuilding inevitably involved the transport of great amounts of material in wheeled vehicles drawn by large animals along the route before the provision of a road surface, and if this occurred in wet weather it would lead to precisely the churning up and mixing of soil that seems to have occurred here. Without dating evidence there can be no certainty as to the postulated Iron Age date of the homogeneous soil taken to represent the underlying track. However, the evidence does direct attention to the increased possibility of an earlier trackway underlying stretches of Akeman Street, and perhaps other Roman roads, prompting further investigation whenever the opportunity arises.

Whether or not Akeman Street had an Iron Age precursor, it is likely that its development into a major arterial route during the early Roman period would have a significant impact on the Iron Age landscape, especially given its relationship to Alchester where an early military fortress was established (Simmonds and Lawrence 2018, 248; Booth et al. 2007, $37)$. In a regional sense, the immediate impact of the Roman conquest of AD 43 on the rural population is not easy to determine (Smith et al. 2016, 150; Booth et al. 2007, 36). There were some sites that did appear to experience disruption, including at Bicester Fields Farm, where the settlement seems to have been abandoned around the middle of the 1st century AD, with the area subsequently given over to fields (Cromarty et al. $\underline{1999}$, 232). A similar sequence is noted at Gravelly Guy in the late Iron Age/early Roman period, when a series of rectilinear paddocks were established (Lambrick and Allen $\underline{2004}, 483$ ).

In contrast to these, several 'new' settlements are recorded from across the region during the early Roman period (Smith et al. 2016, 150) including the settlement or villa complex at Middleton Stoney, originating in the late 1st or early 2nd century AD (Rahtz and Rowley 1984) and the enclosures at Bicester Park (Westgarth and Carlyle 2008). Further evidence of probable continuity was recorded at Heyford Road, where the Roman trackway appears to be a development of the earlier Iron Age features and may indicate the route had gained increased importance (Cook and Hayden 2000, 209) (Figure 2).

\subsection{Medieval/post-medieval}

No evidence of Saxon activity was recorded, except for the radiocarbon date from ditch [04006]. (Table 3; Figure 3). This date, rather than dating the construction of the ditch, may be from intrusive material that became mixed into the ditch fill, possibly indicating that the ditch was still open in some form in the Saxon period. The remaining evidence 
for this period comprised a series of quarry pits and the remains of ridge and furrow, reflecting the agricultural use of the landscape during this period.

\section{Conclusion}

The results from the excavations from across the Angelinos Pipeline present a window onto the prehistoric, Roman and medieval/post-medieval use of the landscape. Although limited, the presence of prehistoric lithics and Chalcolithic/early Bronze Age Beaker sherds hint at an early phase of activity within the development. The Iron Age remains provide evidence for a series of potentially pastoral communities operating within the region, perhaps occupying parts of the landscape on a seasonal basis (Lambrick and Robinson 2009, 90-4). Agricultural regimes would clearly have played a key role in shifts in settlement location during the period. These settlements likely comprised small kin groups, potentially defining areas of pasture and/or territory through a series of land divisions, although the extent and nature of these requires further exploration. It seems that most of the recorded sites had fallen out of use some time before the Roman period, with a paucity of definite late Iron Age features. At many other sites in the region there is clear evidence for a degree of continuity from the Iron Age into the Roman period, although shifts in land boundaries and settlement form have been observed. The most significant Roman remains encountered in the current excavations comprise a section through Akeman Street and a probable contemporary trackway that may cross or join the road. There was no evidence, apart from a single radiocarbon date, of AngloSaxon activity. During the medieval and post-medieval period, the development area is characterised by extensive systems of ridge and furrow, along with probable evidence for quarrying.

\section{Acknowledgements}

Headland Archaeology would like to thank Eight2O (Thames Water in alliance with SMB, a Joint Venture between Skanska, MWH and Balfour Beatty) who commissioned the work. Fieldwork was undertaken by Peter James, Joe Berry, Rhiannon Campbell, Anthony Clifton-Jones, Beth Doyle, John Gillen, Tom Hodgson, Romy Mclntosh, Astrid L. Nathan, Dan Phillips and Phillip Wilson. The post-excavation programme was managed by Michael Tierney and Alex Smith. 


\section{Bibliography}

Albarella, U. 2007 'The end of the Sheep age: people and animals in the late Iron Age' in C. Haselgrove and T. Moore (eds) The Later Iron Age in Britain and Beyond, Oxford: Oxbow Books. 393-406. https://doi.org/10.2307/i.ctvh1dsh9.24

Allen, T.G. 1990 An Iron Age and Romano-British Enclosed Settlement at Watkins Farm, Northmoor, Oxon, Thames Valley Landscapes: the Windrush Valley volume 1, Oxford: Oxford University Committee for Archaeology.

Allen, T., Miles, D. and Palmer, S. 1984 'Iron Age buildings in the Upper Thames region' in B. Cunliffe and D. Miles (eds) Aspects of the Iron Age in Central Southern Britain, Oxford: Oxford University Committee for Archaeology. 89-102.

Allen, M., Davies, A. and Teague, S. 2020 Graven Hill, Bicester, Oxfordshire. Postexcavation assessment and updated project design, Oxford Archaeology: unpublished client report.

Biddulph, E. 2004 'The Iron Age pottery' in C. Stevens, 'Iron Age and Saxon settlement at Juggler's Close, Banbury, Oxfordshire', Oxoniensia LXIX, 404-

10. https://www.oxoniensia.org/volumes/2004/stevens.pdf

Blinkhorn, P. 2009 'The Iron Age assemblage' in S. Ford 'Middle Iron Age occupation at Ells Lane, Bloxham, Banbury, Oxfordshire', Oxoniensia LXXIV, 121-

3. https://www.oxoniensia.org/volumes/2009/ford.pdf

Booth, P. 2011 'Romano-British trackways in the Upper Thames

Valley', Oxoniensia LXXVI, 1-14. https://www.oxoniensia.org/volumes/2011/Booth.pdf

Booth, P. and Madgwick, R. 2016 'New evidence for diverse secondary burial practices in Iron Age Britain: a histological case study', Journal of Archaeological Science 67, 1424. https://doi.org/10.1016/j.jas.2016.01.010

Booth, P., Dodd, A., Robinson, M. and Smith, A. 2007 The Thames Through Time. The archaeology of the gravel terraces of the Upper and Middle Thames, The early historical period: $A D$ 1-1000, Thames Valley Landscapes Monograph 27, Oxford: Oxford

Archaeology.

Bronk Ramsey, C. 2009 'Bayesian analysis of radiocarbon dates', Radiocarbon 51, 33760. https://doi.org/10.1017/S0033822200033865

Case, H. 1956 'Beaker pottery from the Oxford region: 1939-1955', Oxoniensia XXI, 122. https://www.oxoniensia.org/volumes/1956/case.pdf

Clark, A. 1891 The Life and Times of Anthony Wood, Antiquary, of Oxford, 1632-1695, described by Himself, Oxford: Clarendon Press.

Clarke, D. 1970 Beaker Pottery of Great Britain and Ireland, Cambridge: Cambridge University Press. 
Collis, J. 1994 'An Iron Age and Roman cemetery at Owlesbury, Hampshire' in A.P. Fitzpatrick and E. Morris (eds) The Iron Age in Wessex: Recent Work, Salisbury: Association Française D'Etude de L'Age du Fer, Trust for Wessex Archaeology Ltd. 1068.

Cook, S. and Hayden, C. 2000 'Prehistoric and Roman settlement near Heyford Road, Steeple Aston, Oxfordshire', Oxoniensia LXV, 161-

210. https://www.oxoniensia.org/volumes/2000/cook.pdf

Copeland, T. 2009 Akeman Street: moving through Iron Age and Roman landscapes, Gloucestershire: The History Press.

Cromarty, A.M., Foreman, S. and Murray, P. 1999 'The excavation of a late Iron Age enclosed settlement at Bicester Fields Farm, Bicester, Oxon', Oxoniensia LXIV, 153235. https://www.oxoniensia.org/volumes/1999/cromarty.pdf

Cunliffe, B. 2005 Iron Age Communities in Britain, 4th edition, London:

Routledge. https://doi.org/10.4324/9780203973578

De Roche, C. 1978 'The Iron Age pottery' in M. Parrington (ed) The Excavation of an Iron Age Settlement, Bronze Age Ring-ditches and Roman Features at Ashville Trading Estate, Abingdon, (Oxfordshire) 1974-76, CBA Research Report 28/Oxfordshire Archaeological Unit. 40-

74. https://archaeologydataservice.ac.uk/archives/view/cba rr/rr28.cfm / https://doi.org/1 $\underline{0.5284 / 1000332}$

Ellis, P., Hughes, G.A. and Jones, L. 2000 'An Iron Age boundary and settlement features at Slade Farm, Bicester, Oxfordshire: a report on excavations 1996', Oxoniensia LXV, 211-65. https://www.oxoniensia.org/volumes/2000/ellis.pdf

Fearon, J.M. 1971 'Deddington, Oxon', CBA South Midlands Newsletter 1, 9. https://www.archaeologyuk.org/cbasm/index htm files/1\%201971.pdf

Featherstone, R. and Bewley, B. 2000 'Recent aerial reconnaissance in North Oxfordshire', Oxoniensia LXV, 13-

27. https://www.oxoniensia.org/volumes/2000/featherstone.pdf

Fitzpatrick, A. 1997 'Everyday life in Iron Age Wessex' in A. Gwilt and C. Haselgrove (eds) Reconstructing Iron Age Societies, Oxbow Monograph 71, Oxford: Oxbow Books. 178-88.

Gilbert, D. 2005 An Archaeological Evaluation at Gossway Fields, Kirtlington, Oxfordshire, John Moore Heritage Services: unpublished client report. https://doi.org/10.5284/1008177

Gill, H. and Hind, J. (eds) 2014 Solent Thames Research Framework for the Historic Environment: Resource assessment and research agendas, Oxford Wessex Monograph 6, Oxford: Oxford Archaeology. http://eprints.oxfordarchaeology.com/id/eprint/2597 
Grundon, I. 1998 An Archaeological Excavation and Watching Brief on the line of the Finmere B4031 Diversion, Oxfordshire (FDIV 97), AOC Archaeology Ltd: unpublished client report.

Guido, M. 1978 The Glass Beads of the Prehistoric and Roman Periods in Britain and Ireland, Reports of the Research Committee of the Society of Antiquaries of London 35, London: Society of Antiquaries of London.

Hambleton, E. 1999 Animal Husbandry Regimes in Iron Age Britain A comparative study of faunal assemblages from British Iron Age sites, British Archaeology Reports British Series 282, Oxford: Archaeopress. https://doi.org/10.30861/9781841710006

Harding, D.W. 1972 The Iron Age in the Upper Thames Basin, Oxford: Clarendon Press.

Hart, J., McSloy, E., Warman, S. and Mudd, A. 2010 'Later Iron-Age settlement and burial near Aves Ditch: excavations on the Angelinos Pumping Station to Ardley Reservoir Mains Pipeline reinforcement', Oxoniensia LXXV, 133-

65. https://www.oxoniensia.org/volumes/2010/Hart2.pdf

Headland Archaeology 2016 Archaeological Mitigation and Observations for Angelinos Trunk Main, Oxfordshire. Written Scheme of Investigation, Headland Archaeology: unpublished client report.

Hewitt, G. 2016 Archaeological Evaluation on land at Hill Farm, Duns Tew, Oxfordshire, May 2016, MOLA: unpublished client report, no. 16/100.

Hey, G., Booth, P. and Timby, J. 2011 Yarnton: Iron Age and Romano-British Settlement and Landscape, Thames Valley Landscapes Monograph 35, Oxford: Oxford Archaeology.

Hey, G., Bell, C., Dennis, C. and Robinson, M. 2016 Yarnton Neolithic and Bronze Age Settlement and Landscape, Thames Valley Landscapes Monograph 39, Oxford: Oxford Archaeology.

Jennings, D., Muir, J., Palmer, S. and Smith, A. 2004 Thornhill Farm, Fairford, Gloucestershire. An Iron Age and Roman pastoral site in the Upper Thames Valley, Thames Valley Monograph 23, Oxford: Oxford Archaeology.

Johnson, D.E. 1979 An Illustrated History of Roman Roads in Britain, Bourne End: Spurbooks.

Johnston, R. 2001 'Breaking new ground: land tenure and stone clearance during the Bronze Age' in J. Brück (ed) Bronze Age Landscapes Tradition and Transformation, Oxford: Oxbow Books. 99-110.

Johnston, R. 2005 'Pattern without a plan: rethinking the coaxial field systems on Dartmoor, southwest England', Oxford Journal of Archaeology 24(1), 1-

21. https://doi.org/10.1111/j.1468-0092.2005.00222.x

Lambrick, G.H. 1992 'The development of late prehistoric and Roman farming on the Thames gravels' in S. Needham and M.G. Macklin (eds) Alluvial Archaeology in Britain, Oxbow Monograph 27, Oxford: Oxbow Books. 78-105. 
Lambrick, G. and Allen, T. 2004 Gravelly Guy, Stanton Harcourt Oxfordshire, the development of a prehistoric and Romano-British community, Thames Valley Landscapes Monograph 21, Oxford: Oxford Archaeology.

Lambrick, G. and Robinson, M. 1979 Iron Age and Roman Riverside Settlements at Farmoor, Oxfordshire, CBA Research Report 32, Oxfordshire Archaeological Unit: Report 2. https://archaeologydataservice.ac.uk/archives/view/cba rr/rr32.cfm

Lambrick, G. and Robinson, M. 2009 The Thames Through Time. The archaeology of the gravel terraces of the Upper and Middle Thames, Late prehistory 1500 BC-AD 50, Thames Valley Landscapes Monograph 29, Oxford: Oxford Archaeology.

Lang Hall, M. 2014 Angelinos Pipeline, Oxfordshire: An Initial Assessment of the Archaeological Implications, Lang Hall Archaeology: unpublished client report 1405.

Lawrence, S. and Hardy, A. 1996 Hopcrofts Holt Hotel, Steeple Aston, Oxford Archaeology: unpublished client report. https://doi.org/10.5284/1028253

Leeds, E.T. 1938 'Beakers of the Upper Thames district', Oxoniensia III, 731. https://www.oxoniensia.org/volumes/1938/leeds1.pdf

Macphail, R.I. and Crowther, J. 2013 'Glaxo-Smith-Kline site, Ware, Hertfordshire Roman Road Area: Soil Micromorphology (including SEM/EDS), Chemistry and Magnetic Susceptibility', [Report for KDK Archaeology: Institute of Archaeology, University College London].

Macphail, R.I. and Goldberg, P. 2017 Applied Soils and Micromorphology in Archaeology, Cambridge: Cambridge University

Press. https://doi.org/10.1017/9780511895562

Malim, T. and Hayes, L. 2011 'An engineered Iron Age road, associated Roman use (Margary Route 64), and Bronze Age activity recorded at Sharpstone Hill 2009', Transactions of the Shropshire Archaeological and Historical Society 85, 780. https://shropshirearchaeologyhistory.files.wordpress.com/2019/09/shropshiretransactions-vol.-85 sm.pdf

Manning, P. 1898 'Notes on the archaeology of Oxford and its neighbourhood', The Berks, Bucks \& Oxon Archaeological Journal 4, 9-28. https://doi.org/10.5284/1069693

Marter, K. and Brown, K. 2011 'Later Prehistoric and Romano-British pottery' in J. Martin 'Prehistoric, Romano-British and Anglo-Saxon activity at Whitelands Farm,

Bicester', Oxoniensia LXXVI, 201-

11. https://www.oxoniensia.org/volumes/2011/Martin.pdf

Mays, S. 2010 The Archaeology of Human Bones, Routledge:

London. https://doi.org/10.4324/9780203851777

Miles, D., Palmer, S., Smith, A. and Perpetua Jones, G. 2007 Iron Age and Roman Settlement in the Upper Thames Valley, excavations at Claydon Pike and other sites within the Cotswold Water Park, Thames Valley Landscapes Monograph 26, Oxford: Oxford Archaeology. 
Millett, M. and Gowland, R. 2015 'Infant and child burial rites in Roman Britain: a study from East Yorkshire', Britannia 46, 171-89. https://doi.org/10.1017/S0068113X15000100

Morigi, A., Schreve, D., White, M., Hey, G., Garwood, P., Robinson, M., Barclay, A. and Bradley, P. 2011 The Thames Through Time. The archaeology of the gravel terraces of the Upper and Middle Thames, Early prehistory to 1500 BC, Thames Valley Landscapes Monograph 32, Oxford: Oxford Archaeology.

Mulville, J. 2008 'Foodways and social ecologies from the middle Bronze Age to late Iron Age' in J. Pollard (ed) Prehistoric Britain, Oxford: Blackwell Publishing. 225-48.

Needham, S. and Spence, T. 1996 Refuse and Disposal at Area 16 East Runnymede, Runnymede Bridge Research Excavations, Volume 2, London: British Museum Press.

Peacock, D.P.S. 1968 'A petrological study of certain Iron Age pottery from western England', Proceedings of the Prehistoric Society 34, 414-

28. https://doi.org/10.1017/S0079497X00013967

Plot, R. 1705 Natural History of Oxfordshire, being an essay towards the natural history of England 2nd edn, with large additions and corrections: also a short account of the author, Oxford: Leon Lichfield.

Pryor, F. 2006 Farmers in Prehistoric Britain, 2nd edn. Stroud: The History Press.

Rahtz, S. and Rowley, T. 1984 Middleton Stoney: Excavation and Survey in a North Oxfordshire Parish 1970-1982, Oxford University Department for External Studies.

Reimer, P., Austin, W., Bard, E., Bayliss, A., Blackwell, P., Bronk Ramsey, C., Butzin, M., Cheng, H., Edwards, R., Friedrich, M., Grootes, P., Guilderson, T., Hajdas, I., Heaton, T., Hogg, A., Hughen, K., Kromer, B., Manning, S., Muscheler, R., Palmer, J., Pearson, C., van der Plicht, J., Reimer, R., Richards, D., Scott, E., Southon, J., Turney, C., Wacker, L., Adolphi, F., Büntgen, U., Capano, M., Fahrni, S., Fogtmann-Schulz, A., Friedrich, R., Köhler, P., Kudsk, S., Miyake, F., Olsen, J., Reinig, F., Sakamoto, M., Sookdeo, A. and Talamo, S. 2020 'The IntCal20 Northern Hemisphere radiocarbon age calibration curve (0-55 cal kBP)', Radiocarbon 62, 725-

57. https://doi.org/10.1017/RDC.2020.41

Rentzel, P., Nicosia, C., Gebhardt, A., Brönnimann, D., Pümpin, C. and Ismail-Meyer, I. 2017 'Trampling, poaching and the effects of traffic' in C. Nicosia and G. Stoops (eds) Archaeological Soil and Sediment Micromorphology, London: John Wiley and Sons Ltd. 281-98. https://doi.org/10.1002/9781118941065.ch30

Salter, C. and Ehrenreich, R. 1984 'Iron Age metallurgy in Central Southern Britain' in B. Cunliffe and D. Miles (eds) Aspects of the Iron Age in Southern Britain, Oxford:

University of Oxford Committee for Archaeology. 126-46.

Salway, P. 1999 'Roman Oxfordshire', Oxoniensia LXIV, 1-23.

https://www.oxoniensia.org/volumes/1999/salway.pdf

Salzman, L.F. (ed) 1939 A History of the County of Oxford Volume 1, London: University of London. https://www.british-history.ac.uk/vch/oxon/vol1 
Sauer, E.W. 2005 Linear Earthwork, Tribal Boundary and Ritual Beheading: Aves Ditch from the Iron Age to the early Middle Ages, British Archaeology Reports British Series 402, Oxford: Archaeopress. https://doi.org/10.30861/9781841718996

Sauer, E.W. 2006 'Alchester: origins and destiny of Oxfordshire's earliest Roman site', Oxoniensia LXXI, 1-31. https://www.oxoniensia.org/volumes/2006/sauer.pdf

Serjeanston, D. 2007 'Intensification of animal husbandry in the Late Bronze Age? The contribution of sheep and pigs' in C. Haselgrove and R. Pope (eds) The Earlier Iron Age in Britain and the near Continent, Oxford: Oxbow Books. 80-

93. https://doi.org/10.2307/j.ctvh1dwaj.7

Simmonds, A. and Lawrence, S. 2018 Footprints from the Past. The south-eastern extramural settlement of Roman Alchester and rural occupation in its hinterland: The archaeology of East West Rail Phase 1, Oxford Archaeology Monograph 28, Oxford: Oxford Archaeology.

Smith, A., Allen, M., Brindle, T. and Fulford, M. 2016 The Rural Settlement of Roman Britain, New Visions of the Countryside of Roman Britain Vol. 1, Britannia Monograph 29, London: Society for the Promotion of Roman Studies. https://archaeologydataservice.ac.uk/library/browse/issue.xhtml?recordld=1161 $\underline{495}$

Smith, A., Allen, M., Brindle, T., Fulford, M., Lodwick, L. and Rohnbogner, A. 2018 Life and Death in the Countryside of Roman Britain, Britannia Monograph 31, London: Society for the Promotion of Roman Studies. https://archaeologydataservice.ac.uk/library/browse/issue.xhtml?recordld=1161 $\underline{497}$

Spencer, P., Boucher, A. and Tierney, M. 2017 Archaeological mitigation and observations for Angelinos Trunk main scheme, Oxfordshire, Post-excavation assessment and updated project design, Headland Archaeology: unpublished client report.

Stratascan 2015 Angelinos Pipeline, Oxfordshire, Stratascan: unpublished client report.

Tomber, R. and Dore, J. 1998 The National Roman Fabric Reference Collection: A Handbook, Museum of London Archaeology Service Monograph 2, London: Museum of London Archaeology Service. http://romanpotterystudy.org.uk/nrfrc/

Wait, G.A. 1985 Ritual and Religion in Iron Age Britain, British Archaeology Reports British Series 149, Oxford: Archaeopress. https://doi.org/10.30861/9780860543626

Waldron, T. 2009 Palaeopathology, Cambridge: Cambridge University Press.

Wessex Archaeology 2006 Land South-west of Bicester, Oxfordshire, Report on Archaeological Evaluation, Wessex Archaeology: unpublished client report, report reference 63560.01.

Westgarth, A. and Carlyle, S. 2008 'A Roman settlement at Bicester Park, Bicester, Oxfordshire', Oxoniensia LXXIII, 12147. https://www.oxoniensia.org/volumes/2008/westgarth.pdf 
Whimster, R. 1977 'Iron Age burial in Southern Britain', Proceedings of the Prehistoric Society 43, 317-27. https://doi.org/10.1017/S0079497X00010446

Whimster, R. 1981 Burial Practices in Iron Age Britain, British Archaeology Reports British Series 90, Oxford: Archaeopress.

Wilson, B. and Bramwell, D. 1993 'Bone and shell evidence' in T.G. Allen and M.A. Robinson (eds) Mingies Ditch Hardwick-with-Yelford, Oxon, Thames Valley Landscapes: the Windrush Valley volume 2, Oxford: Oxford University Committee for Archaeology. 168-91.

Wing, W. 1877 Annals of Rousham in the County of Oxford, Dryden.

Winton, H. 2001 'A possible Roman Small Town at Sansom's Platt, Tackley, Oxon', Britannia 32, 304-9. https://doi.org/10.2307/526966 